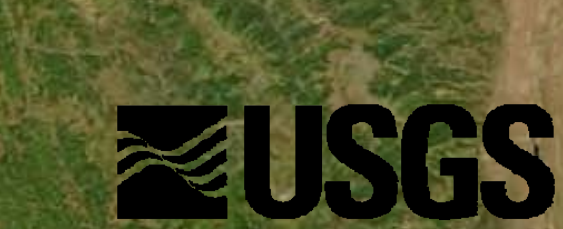

Ex is of In Valley Drainage Management Strategies for the Western San Joaquin Valley, California.

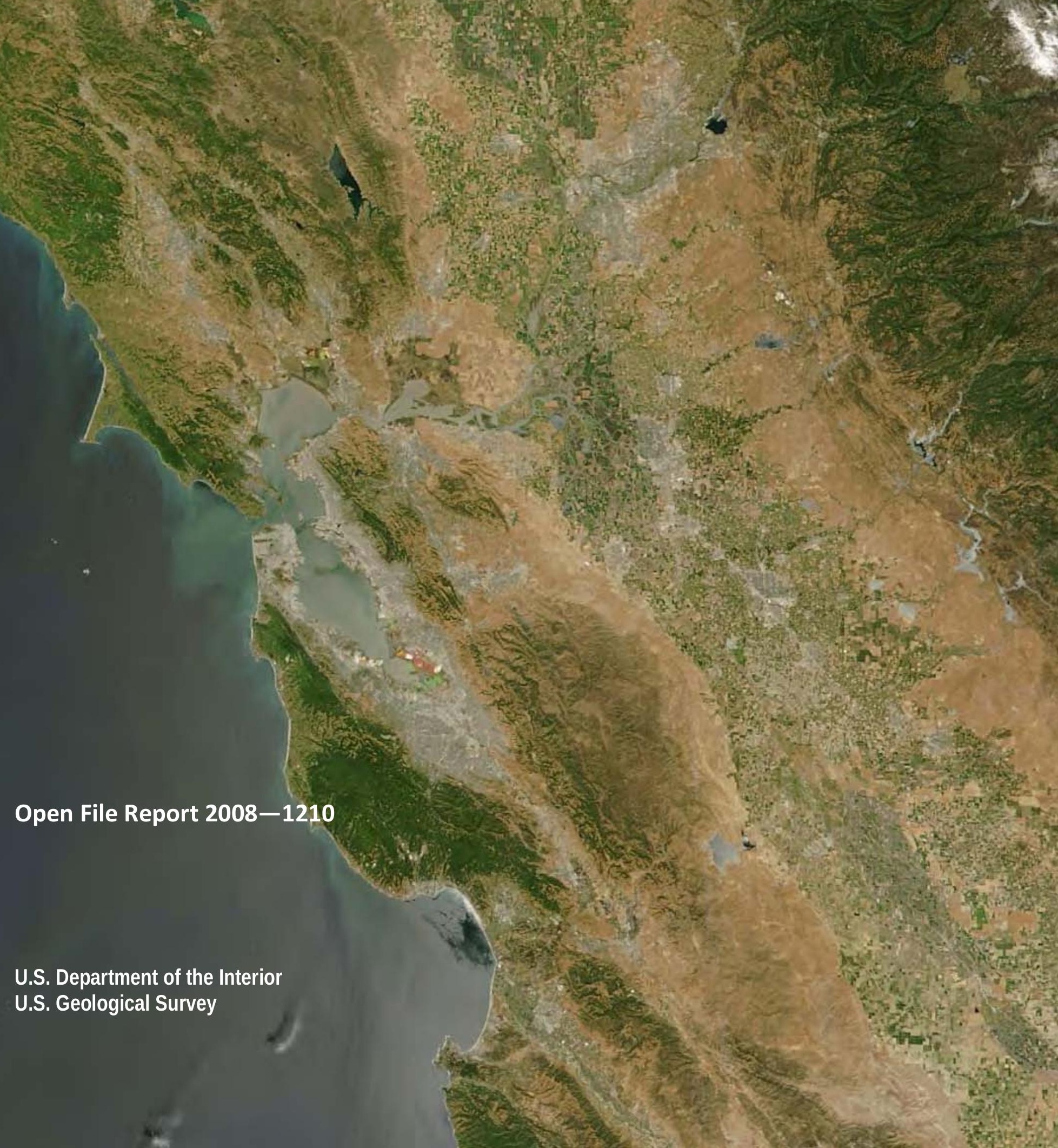


Cover Photo: San Joaquin-Sacramento River Delta, California, NASA, 2006 


\section{Technical Analysis of In-Valley Drainage Management Strategies for the Western San Joaquin Valley, California}

By Theresa S. Presser and Steven E. Schwarzbach

Open File Report 2008-1210

U.S. Department of the Interior

U.S. Geological Survey 


\section{U.S. Department of the Interior \\ DIRK KEMPTHORNE, Secretary}

\section{U.S. Geological Survey \\ Mark D. Myers, Director}

U.S. Geological Survey, Reston, Virginia 2008

For more information on the USGS—-the Federal source for science about the Earth, its natural and living resources, natural hazards, and the environment: World Wide Web: http://www.usgs.gov

Telephone: 1-888-ASK-USGS

Suggested citation:

Presser, T. S., Schwarzbach, S. E., 2008, Technical Analysis of In-Valley Drainage Management Strategies for the Western San Joaquin Valley, California, U.S. Geological Survey, Open-File Report 2008-1210, 37 p. [http://pubs.usgs.gov/of/2008/1210/].

Any use of trade, product, or firm names is for descriptive purposes only and does not imply endorsement by the U.S. Government.

Although this report is in the public domain, permission must be secured from the individual copyright owners to reproduce any copyrighted material contained within this report. 


\section{Contents}

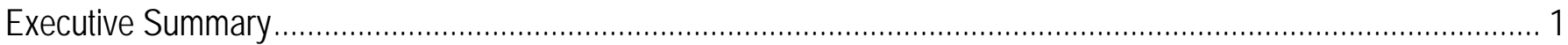

Introduction

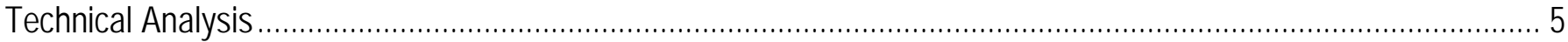

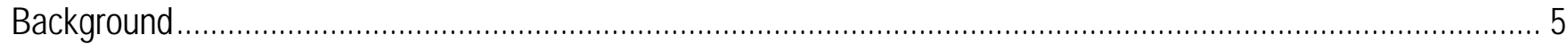

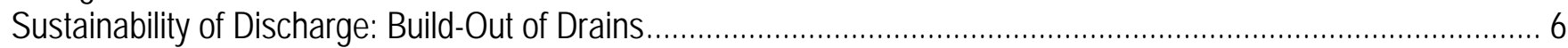

Reduction in Applied Water: Land Retirement and Isolation of Selenium ...................................................... 9

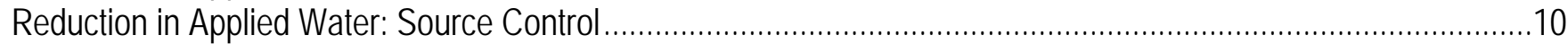

Hydrologic Balance: Regional Groundwater Extraction from the Semi-Confined Aquifer....................................12

Storage of Concentrated Drainage Water on Land Surface: Mass Balance of Salt and Selenium in Waste

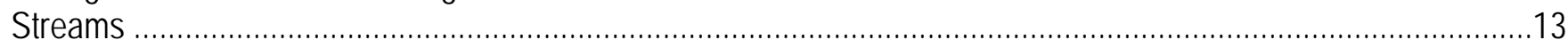

Ecological Risk of Selenium: integration of habitat areas in scaled-up reuse areas and enhanced evaporation

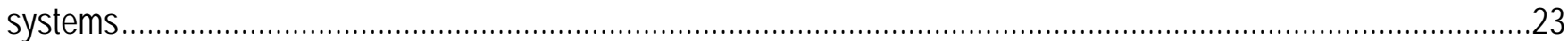

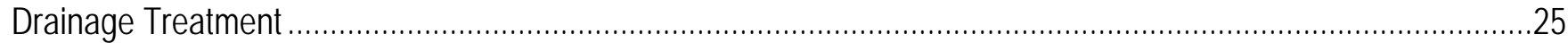

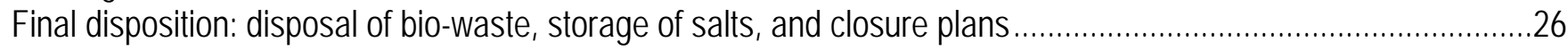

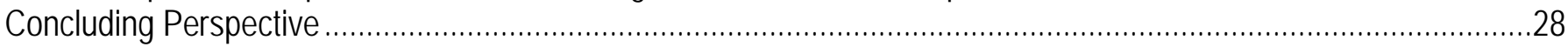

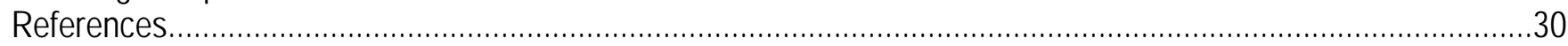

Appendix A: Description of Drainage Management Alternatives and Plans..........................................................33

SLU Plan proposed in USFWS Conceptual Monitoring, Compliance, and Adaptive Management

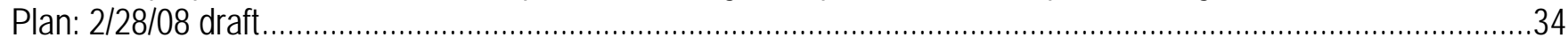

SLU Plan proposed in USBR Handout \#4, San Luis Unit Drainage Implementation Plan, dated 2/12/08 .................35

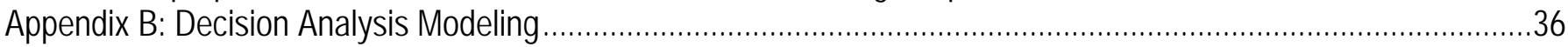

\section{Figures}

Figure 1.Projection of drained area, selenium loads, and salt loads (i.e. drainage need) for 1 to 50 years for the Westlands Water District (SLDFRE Planning Alternatives Report, 2001) ............................................................ 7

Figure 2.Projection of selenium and salt concentrations (i.e. drainage need) for 1 to 50 years for the Westlands Water District (SLDFRE Planning Alternatives Report, 2001) ............................................................................ 8

Figure 3.Projection of drained area, selenium loads, and salt loads (i.e. drainage need), for 1 to 50 years for the Northerly San Luis Unit districts (SLDFRE Planning Alternatives Report, 2001) .................................................... 8

Figure 4.Projection of selenium and salt concentrations (i.e. drainage need) for 1 to 50 years for the Northerly San Luis Unit districts (SLDFRE Planning Alternatives Report, 2001) ................................................................. 9

Figure 5.Components of sequential waste-stream for recently proposed in-valley drainage management plan.

Figure 6. Selenium and salt mass balance for SLDFRE EIS in-valley alternative with current acres retired (combined Westlands Area and Northerly Area).

Figure 7. Selenium and salt mass balance for SLDFRE EIS in-valley/groundwater quality land retirement alternative with 100,000 acres retired (combined Westlands Area and Northerly Area)...

Figure 8. Selenium and salt mass balance for SLDFRE EIS in-valley/water needs land retirement alternative with 200,000 acres retired (combined Westlands Area and Northerly Area).

Figure 9. Selenium and salt mass balance for SLDFRE EIS in-valley/drainage-impaired lands land retirement alternative with 300,000 acres retired (combined Westlands Area and Northerly Area).

Figure 10. Selenium and salt mass balance for recently proposed in-valley management plan with 100,000 acres retired (combined Westlands Area and Northerly Area).

Figure 11. Selenium and salt mass balance for a variation of recently proposed in-valley management plan (combined Westlands Area and Northerly Area; Westlands Area at full capacity). 
Figure 12. Selenium and salt mass balance for theoretical in-valley alternative with equal proportion of drainage stored in reuse as that processed through waste-stream to reverse osmosis, bio-treatment, and enhanced solar evaporation (combined Westlands Area and Northerly Area).

\section{Tables}

Table 1. Simulations of drainage produced under different land retirement alternative........................................... 9

Table 2. Simulations of drainage produced under moderate recharge reduction. ...................................................11

Table 3. Simulations of drainage produced under maximum recharge reduction ....................................................11

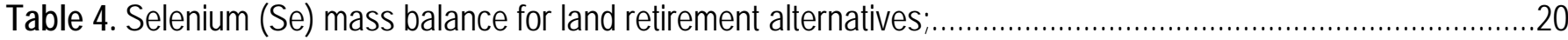

Table 5. Selenium (Se) mass balance for Land Retirement Alternatives: calculated storage. . ..................................21

Table 6. Average egg selenium concentrations ( $\mu \mathrm{g} / \mathrm{g}$, dry weight) for bird eggs collected in April, May, and June, 2003 from the Panoche Drainage District reuse area.

Table 7. Range of egg selenium concentrations ( $\mu \mathrm{g} / \mathrm{g}$, dry weight) for bird eggs collected from 2003 through 2006 from the Panoche Drainage District reuse area.

Table 8. Geometric mean egg selenium concentration ( $\mu \mathrm{g} / \mathrm{g}$, dry weight) for bird eggs collected from 2003 through 2006 from the Panoche Drainage District's reuse area. 


\section{Conversion Factors}

Inch/Pound to SI

\begin{tabular}{|c|c|c|}
\hline Multiply & By & To obtain \\
\hline \multicolumn{3}{|c|}{ Area } \\
\hline acre & 4,047 & square meter $\left(\mathrm{m}^{2}\right)$ \\
\hline acre & 0.4047 & hectare (ha) \\
\hline acre & 0.4047 & square hectometer $\left(\mathrm{hm}^{2}\right)$ \\
\hline acre & 0.004047 & square kilometer $\left(\mathrm{km}^{2}\right)$ \\
\hline square foot $\left(\mathrm{ft}^{2}\right)$ & 929.0 & square centimeter $\left(\mathrm{cm}^{2}\right)$ \\
\hline square foot $\left(\mathrm{ft}^{2}\right)$ & 0.09290 & square meter $\left(\mathrm{m}^{2}\right)$ \\
\hline square inch $\left(\right.$ in $\left.^{2}\right)$ & 6.452 & square centimeter $\left(\mathrm{cm}^{2}\right)$ \\
\hline section (640 acres or 1 square mile) & 259.0 & square hectometer $\left(\mathrm{hm}^{2}\right)$ \\
\hline square mile $\left(\mathrm{mi}^{2}\right)$ & 259.0 & hectare (ha) \\
\hline square mile $\left(\mathrm{mi}^{2}\right)$ & 2.590 & square kilometer $\left(\mathrm{km}^{2}\right)$ \\
\hline \multicolumn{3}{|c|}{ Volume } \\
\hline acre-foot (acre-ft) & 1,233 & cubic meter $\left(\mathrm{m}^{3}\right)$ \\
\hline acre-foot (acre-ft) & 0.001233 & cubic hectometer $\left(\mathrm{hm}^{3}\right)$ \\
\hline
\end{tabular}

\section{Flow rate}

acre-foot per day (acre-ft/d)

acre-foot per year (acre-ft/yr)

acre-foot per year (acre-ft/yr)
0.01427

0.001233 cubic meter per second $\left(\mathrm{m}^{3} / \mathrm{s}\right)$

cubic meter per year $\left(\mathrm{m}^{3} / \mathrm{yr}\right)$

cubic hectometer per year $\left(\mathrm{hm}^{3} / \mathrm{yr}\right)$ 


\title{
Technical Analysis of In-Valley Drainage Management Strategies for the Western San Joaquin Valley
}

\author{
By Theresa S. Presser and Steven E. Schwarzbach
}

\section{Executive Summary}

The western San Joaquin Valley is one of the most productive farming areas in the United States, but salt-buildup in soils and shallow groundwater aquifers threatens this area's productivity. Elevated selenium concentrations in soils and groundwater complicate drainage management and salt disposal. In this document, we evaluate constraints on drainage management and implications of various approaches to management considered in:

$>$ the San Luis Drainage Feature Re-Evaluation (SLDFRE) Environmental Impact Statement (EIS) (about 5,000 pages of documentation, including supporting technical reports and appendices);

$>$ recent conceptual plans put forward by the San Luis Unit (SLU) contractors (i.e., the SLU Plans) (about 6 pages of documentation);

$>$ approaches recommended by the San Joaquin Valley Drainage Program (SJVDP) (1990a); and

$>$ other U.S. Geological Survey (USGS) models and analysis relevant to the western San Joaquin Valley.

The alternatives developed in the SLDFRE EIS and other recently proposed drainage plans (refer to appendix A for details) differ from the strategies proposed by the San Joaquin Valley Drainage Program (1990a). The Bureau of Reclamation (USBR) in March 2007 signed a record of decision for an in-valley disposal option that would retire 194,000 acres of land, build 1,900 acres of evaporation ponds, and develop a treatment system to remove salt and selenium from drainwater. The recently proposed SLU Plans emphasize pumping drainage to the surface, storing approximately $33 \%$ in agricultural water re-use areas, treating selenium through biotechnology, enhancing the evaporation of water to concentrate salt, and identifying ultimate storage facilities for the remaining approximately $67 \%$ of waste selenium and salt. The treatment sequence of reuse, reverse osmosis, selenium bio-treatment, and enhanced solar evaporation is unprecedented and untested at the scale needed to meet plan requirements.

All drainage management strategies that have been proposed seek to reduce the amount of drainage water produced. One approach is to reduce the amount of drainage per irrigated acre. From modeling simulations performed for the SLDFRE EIS of the Westlands Area of the SLU, theoretical minimums that can be achieved range from approximately 0.16 to 0.25 acre-feet per acre per year (AF/acre/year). Minimum production rates from the Northerly Area 
of the SLU are theorized as being much higher, approximately 0.42 to 0.28 $\mathrm{AF} / \mathrm{acre} / \mathrm{year}$. Rates shown in the SLU Plans for drained acres from the two areas combined are $0.5 \mathrm{AF} /$ acre/year at the subsurface drain stage and 0.37 $\mathrm{AF} / \mathrm{acre} / \mathrm{year}$ after a series of on-farm and regional measures are instituted.

Land retirement is a key strategy to reduce drainage because it can effectively reduce drainage to zero if all drainage-impaired lands are retired. Land retirement alternatives considered in the SLDFRE EIS differ for the two areas analyzed in the SLU. The Northerly Area is to retire a nominal 10,000 acres and Westlands is to retire up to 300,000 acres. The initial land retirement option recently put forth in the SLU Plans predicted drainage volume reductions that are consistent with 200,000 acres of land retirement, but only 100,000 acres of land retirement was proposed.

Within the proposed area of drainage there are, for all practical purposes, unlimited reservoirs of selenium and salt stored within the aquifers and soils of the valley and upslope in the Coast Ranges. Salt imported in irrigation water is estimated to be at least 1.5 million tons per year for the Westlands and Northerly Areas (SJVDIP, 1998). Analysis of the land retirement alternatives presented in the SLDFRE EIS indicates that land retirement of a minimum of only 100,000 acres results in the annual pumping to the surface of 20,142 pounds of selenium or about a million pounds of selenium over a 50 year period. Retiring 200,000 acres results in an annual pumping of 14,750 pounds of selenium; and retiring 300,000 acres reduces selenium pumped to the surface annually to 8,756 pounds, almost all of which is produced in the Northerly Area.

A selenium mass balance analysis by USGS quantifies the amount of selenium, in general, exposed on the landscape and specifically contained in each waste-stream component (e.g., regional collector, reuse area, reverse osmosis facility, selenium bio-treatment plant, and enhanced solar evaporator system) for the SLDFRE EIS land retirement alternatives and recently proposed SLU Plans. A third of the selenium is lost in the first step at the agriculture water reuse areas. Selenium bio-treatment, if successful, would remove another $66 \%$ of the selenium from the waste stream, leaving a wastestream of $10 \mu \mathrm{g} / \mathrm{L}$ to be evaporated. Salt produced and stored at the surface in solar evaporators in the 100,000-acre, 200,000-acre and 300,000-acre alternatives totals $412,000,307,000$ and 181,000 tons per year. At 50 years, the 100,000-acre land retirement option will require salt storage of 20 million tons in these evaporators or landfills. This salt will be contaminated with a variety of trace elements common in drainage waters including selenium, boron, molybdenum, chromium, and arsenic.

Storage of salts in the aquifer below irrigated lands will also occur. Useable groundwater may be defined by the amount of total dissolved solids it contains. Regardless of what drainage plan is implemented, the amount of salt in groundwater will increase. Based on projections of future total dissolved solids in groundwater of the Westland and Northerly Areas, the useable life of the aquifer under various irrigation and drainage management goals is estimated to be between 25 and 220 years. 
The hydrologic imbalance in the western San Joaquin Valley can be partly addressed through a program that substitutes groundwater pumping for surface water delivery, thus helping to shift the groundwater budget from large surplus to small deficit and to stem any expansion of the drainage problem through time with continued irrigation. USGS models estimate that if pumped ground water is substituted for surface water deliveries there are several significant benefits: (1) the water table will be lowered under existing impaired lands; (2) the future area of land impacted by bare soil evaporation will be reduced; (3) up to 400,000 acre feet of surface water deliveries will be offset by groundwater pumping of about 320,000 AF/year and 80,000 AF/year by improvements in ground-water efficiency; and (4) the amount of drainwater that would need to be brought to the surface and treated will be reduced, thus reducing both cost and potential ecological risk. Coupling this type of ground-water flow model with salt and selenium biogeochemical models would yield an integrated approach to predicting water, salt, and selenium transport and identifying any potential degradation of aquifer resources that might accompany such a regional program.

Given the amount of analysis and documentation available from the SJVDP and recent re-evaluations of drainage management, the USGS identifies not a lack of information, but rather a lack of decision analysis tools to enable meeting the combined need of sustaining agriculture, providing drainage service, and minimizing impacts to the environment. A more formal decision-making process may better address uncertainties (e g., the scaling up of re-use areas and enhanced solar evaporators; the feasibility of bio-treatment of drainwater containing 32,500 mg/L salt); help optimize combinations of specific drainage management strategies; and document underlying data analysis for future use. The benefits of such a process of decision analysis (refer to appendix B for details) are that it provides the flexibility to move forward in the face of uncertainty. It does, however, require long-term collaboration among stakeholders and a commitment to formalized adaptive management. 


\section{Introduction}

The primary goal for the western San Joaquin Valley under the recently proposed drainage management plan by the San Luis Contractors remains the same as that defined by the SJVDP: lower the near- surface water table in waterlogged, saline land areas to help sustain agriculture (SJVDP, 1990a; USBR, 2008). Complicating that goal, however, is the complexity of managing selenium, a toxicant to fish and wildlife that is leached from agricultural lands (Presser and Ohlendorf, 1987). The Westlands Water District within the San Luis Unit of the Central Valley Project is potentially the greatest generator of selenium when compared to the more northerly and southerly areas because its lands encompass the Panoche Creek alluvial fan (Presser, 1994). This fan and inter-fan area receive the most seleniferous runoff and erosion from the Coast Ranges.

The SJVDP (1990a) identified three planning alternatives to achieve sustained agriculture and address selenium:

$>$ conservation and recycling of irrigation-agricultural water;

$>$ retirement of irrigated land overlying areas of containing shallow ground water with elevated concentrations of selenium;

$>$ extraction of irrigable water from deep within the semi-confined aquifer.

In terms of selenium, isolating selenium in the aquifer was identified as beneficial in comparison to discharge to surface impoundments or the San Joaquin River. Mitigation for selenium would still be necessary, but the potential for saving water through improved source control would help offset adverse effects by providing additional wetlands. Land retirement could also create terrestrial habitat, but only up-gradient lands would be considered unaffected by selenium.

The SJVDP (1990a) addressed identifying the mix of strategies with associated performance criteria (triggers) and contingency options that were needed to achieve a certain quantitative outcome (for example, see figure 28 in SJVDP, 1990a). The criterion most used in the SJVDP to measure progress was a reduction in drainage (i.e., a decrease in the amount of acre-feet of drainage produced per acre per year, AF/acre/year). A minimum amount of water is needed to achieve salt balance (i.e., some water must pass the root zone to leach salt and maintain soil productivity). However, the amount above that, called non-beneficial deep percolation, was considered to contribute to problem water. Thus, the potential for reduction in deep percolation and the amount of problem water produced can be used to compare and objectify current alternatives and proposals. Inherent in all drainage reduction alternatives is a reduction in applied water (i.e., water retirement) because drainflow is directly proportional to shallow groundwater table levels. Feasibility of implementing options also depended on compensating benefits in the form of reduced costs of handling drainage regionally and in economic return to landowners from the sale and lease of the water supply no longer needed for irrigation (SJVDP, 1990a).

Alternatives for providing drainage service for the western San Joaquin Valley were recently re-evaluated (USBR, 2001; 2002; 2005) (refer to appendix A for detailed descriptions). These efforts culminated in a SLDFRE EIS in 2006 and a Record of Decision (ROD) for the project in 2007. Of the in-valley options shown in the SLDFRE EIS, land retirement of all drainage-impaired lands (Drainage-Impaired Area alternative) was demonstrated as the preferred alternative. Under this alternative, 300,000 acres of land would be retired in Westlands Water District and drainage production in that district would theoretically be reduced to zero. In the ROD, retiring 200,000 acres of land (the Water Needs alternative) was selected as the alternative to be implemented based on further considerations of State and local impacts to agriculture. This alternative would retire lands such that the water needs of the lands remaining in production could be met by the foreseeable water 
supply from the Central Valley Project (CVP) water contracts (assumed at 70\%) held by the associated water districts and groundwater resources for the area. The retired acreage would include lands with selenium concentrations $>20 \mu \mathrm{g} / \mathrm{L}$ in the shallow ground water. A third land retirement alternative (the Groundwater Quality alternative) considered in the SLDFRE EIS was to retire all lands with selenium concentrations $>50 \mu \mathrm{g} / \mathrm{L}$ in the shallow ground water (i.e., approximately 100,000 acres). Although not explicitly stated, the option recently proposed by Westlands Water District is similar to the Water Needs alternative in terms of regional drainage produced, but acres of land to be retired is unclear. An estimate of 100,000 acres land retirement has been suggested, which would include lands retired under previous settlement agreements, but not lands specifically targeted to contain selenium as envisioned by the SJVDP.

In recent negotiations, Westland Water District has proposed to assume the responsibility of drainage service using an array of drainage reduction, treatment, and disposal options, but not necessarily with land retirement as the primary driver (appendix A). Hence, as with the SJVDP, a mix of strategies is being proposed that depends on different elements of drainage reduction and that potentially could serve many needs (e.g., lowering the water table; agricultural suitability; selenium containment). Given here is a preliminary analysis to help understand, frame, and quantify various drainage management strategies. In addition to the SLDFRE EIS and supporting information for the recent proposal, our analysis is mainly based on USGS led investigations and collaborative program data [e.g., SJVDP, 1990a, b; San Joaquin Valley Drainage Implementation Program (SJVDIP), 1998; SJVDIP Land Retirement Committee Report, 1999; Presser, 1987; 1994; Belitz and Phillips, 1993; Brush et al., 2006; Presser and Luoma, 2006). Presser and Luoma (2006) recently compiled the drainage history of the San Joaquin Valley and documented current reservoirs of salt and selenium in order to understand and model selenium loads that potentially would be available if out-of-valley or in-valley disposal was again considered on a regional basis (see especially documentation of San Joaquin Valley loading scenarios and appendices A to D of Presser and Luoma, 2006).

\section{Technical Analysis}

\section{Background}

In planning for an envisioned hydrologic balance for the valley, a distinction was made between managing the accumulated hydrologic imbalance (area of affected land) and managing the annual hydrologic imbalance (rate of water table rise) (SJVDP, 1990a; Presser and Luoma, 2006). Short-term objectives would work toward hydrologic balance by stemming the rate of deterioration, while reclaiming existing problem lands would require releasing from storage a large accumulation of water and salt. Achieving hydrologic balance would not achieve salt balance. Salts would continue to accumulate in the soils and aquifers of the San Joaquin Valley. Managed volume of drainage discharge would increase over a hypothesized 100-year planning period (USBR, 1978, 1983). Salt loads were calculated for a period of 50 years into the future, with a maximum release occurring after 40 years of discharge. Later estimates (USBR, 1983), also planned for 100 years of discharge to an out-of-valley drainage canal, showed a slowing in the rate of increase after 40 years.

A more recent evaluation in 1998 of salt importation showed a total annual imported salt of 1.5 million tons per year to the western San Joaquin Valley (SJVDIP,1998). For the Westlands Water District alone, because there is no drainage outlet, the salt input was estimated at 453,000 tons of salt/year. The predicted conditions in the Westlands Water District showed the largest proportion of internal salt to imported salt for the five areas considered (CH2M HILL, 1988). Here, importation of higher quality water would have a diminished effect compared to other areas because of this large reservoir of salt. The Northern and Grassland areas showed high proportions of imported salt to 
internal salt and relatively low salt accumulations because of the availability of the San Joaquin River for salt discharge.

In terms of assessing the build-up of selenium, calculation of the amounts of selenium stored in the soils and aquifers of the western San Joaquin Valley confirm that the nature of accumulation and potential release of selenium contaminated drainage is massive (Presser and Luoma, 2006).

Calculations based on two scenarios show that no long-term reduction in selenium discharge would be expected for 63 to 304 years at the lower range of selenium reservoir projections and at an assumed selenium removal rate of 42,785 pounds (lbs) of selenium/year. A drainage alternative that exports wastewaters outside of the valley may slow the degradation of valley resources, but drainage alone cannot alleviate the selenium build-up in the valley, at least within a century, even if influx of selenium from the Coast Ranges could be curtailed.

Selenium poses a hazard to fish and wildlife because of its reproductive toxicity at environmentally relevant concentrations and its tendency to accumulate in food chains (Skorupa, 1998). The San Joaquin Valley provides critically important habitat for wintering waterfowl of the Pacific Flyway. Eight to twelve million ducks and geese, along with hundreds of thousands of shorebirds and other marsh birds annually winter or pass through the valley. The history of the ecological impacts of disposal of selenium at Kesterson National Wildlife Refuge within the valley is well documented (e.g., Presser and Ohlendorf, 1987; SJVDP, 1990a, b). Additionally from 1986 to 1993, the National Irrigation Water-Quality Program (NIWQP) of the U.S. Department of the Interior (USDOI) studied whether contamination was induced by irrigation drainage in 26 areas of the western United States. This program developed guidelines to interpret effects on biota of selenium (USDOI, 1998). These guidelines, along with revisions based on more recent studies and modeling, can be used to interpret and guide management and mitigation of the risk of selenium in food chains and wildlife. (Presser and Luoma, 2006). A recent proposed out-of-valley solution to extend the San Luis Drain to convey drainage from the valley to the San Francisco Bay-Delta was found to present substantial ecological risk due to selenium (SLDFRE EIS, 2006; Presser and Luoma, 2006).

In terms of degradation of groundwater quality for irrigation, management of drainage as presented in the SJVDP again tended to enhance near-term (up to 50 years) protection of soils and offsite impacts of drainage discharges, while continuing to diminish the life of the westside aquifers for irrigation use. The SJVDP estimated under certain assumed conditions for the lands of the SLU that the remaining useful life of the semi-confined aquifer (usable groundwater containing less than 1250 $\mathrm{mg} / \mathrm{L}$ Total Dissolved Solids, TDS) was 25 to 150 years at a minimum and 65 to 220 years on average. Schoups et al. (2005) more recently used integrated soil chemistry and regional-scale hydrology modeling to show that sustainability of agriculture in the western San Joaquin Valley is threatened in two ways: (1) the storage of dissolved salt has increased continuously since 1945; and (2) deeper aquifers are accumulating salt, thereby degrading deep groundwater quality.

\section{Sustainability of Discharge: Build-Out of Drains}

The recent drainage management plan proposes to continue managing the annual imbalance, but also in the long-term proposes to start draining the accumulated salt and selenium from aquifers and soils of the San Joaquin Valley. In an initial projection of drainage need the projected drained acreage at the build-out of the project in 50 years is 225,000 acres for the Westlands Area and 35,600 acres for the Northerly Area Area. (SLDFRE Preliminary Alternative Report, 2001, section 3). Nominal values of drainage volume $(60,000 \mathrm{AF} / \mathrm{year})$ and selenium concentration $(50 \mu \mathrm{g} / \mathrm{L})$ for the Westlands Area showed an average of $8,800 \mathrm{lbs}$ selenium discharged per year at the build-out of the 
project at 50 years. Nominal values of drainage volume (10,500 AF/year) and selenium concentration $(90 \mu \mathrm{g} / \mathrm{L})$ for the Northerly Area showed an average of 2,500 lbs selenium discharge per year at the build-out of the project at 50 years. Although these values have been revised on a more specific basis (refer to later discussion, tables, and figures), the general scale of the proposed project and the trend of the analysis remain relevant for the drainage areas. For Westlands Area, (a) acreage, volume, salt and selenium loads increase for 40 years and then may remain at those levels for perpetuity; (b) salt and selenium concentrations decrease for 20-30 years to constant concentrations and then may remain at those levels for perpetuity (figures 1 and 2). For the Northerly Area, (a) acreage remains constant; (b) volume and salt and selenium loads decrease for 20 years and then may remain at those levels for perpetuity; (b) salt and selenium concentrations decrease for 20 years to constant concentrations and then may remain at those levels for perpetuity (figures 3 and 4). Figures 1 to 4 also illustrate to some degree the incremental installation of subsurface drains. As soon as drainage service is available, the existing area in the north Westlands Area with drains would connect immediately. Within the first 10 years, approximately $30 \%$ of drains would be installed, while the installation of the remaining $70 \%$ would proceed over the next 40 years as a linear increase. In the Northerly Area, a linear increase is assumed. Drains would not discharge to the reuse facilities until construction of disposal facilities were within two years of completion.

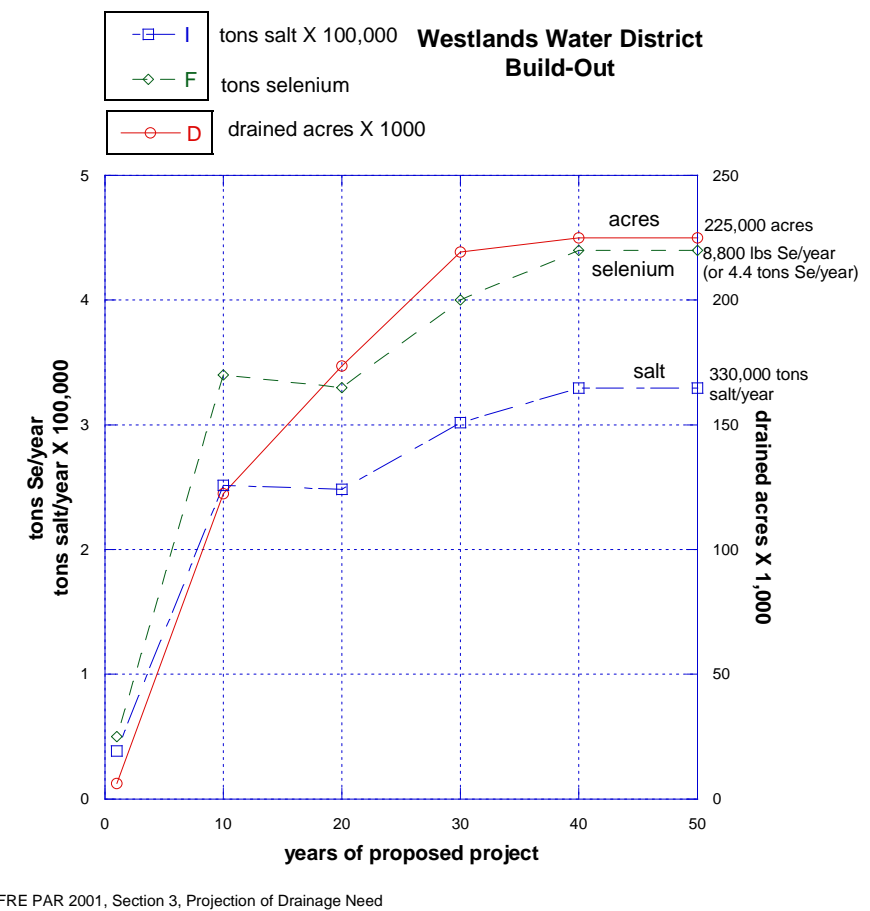

Figure 1. Projection of drained area, selenium loads, and salt loads (i.e. drainage need) for 1 to 50 years for the Westlands Water District (SLDFRE Planning Alternatives Report, 2001). 


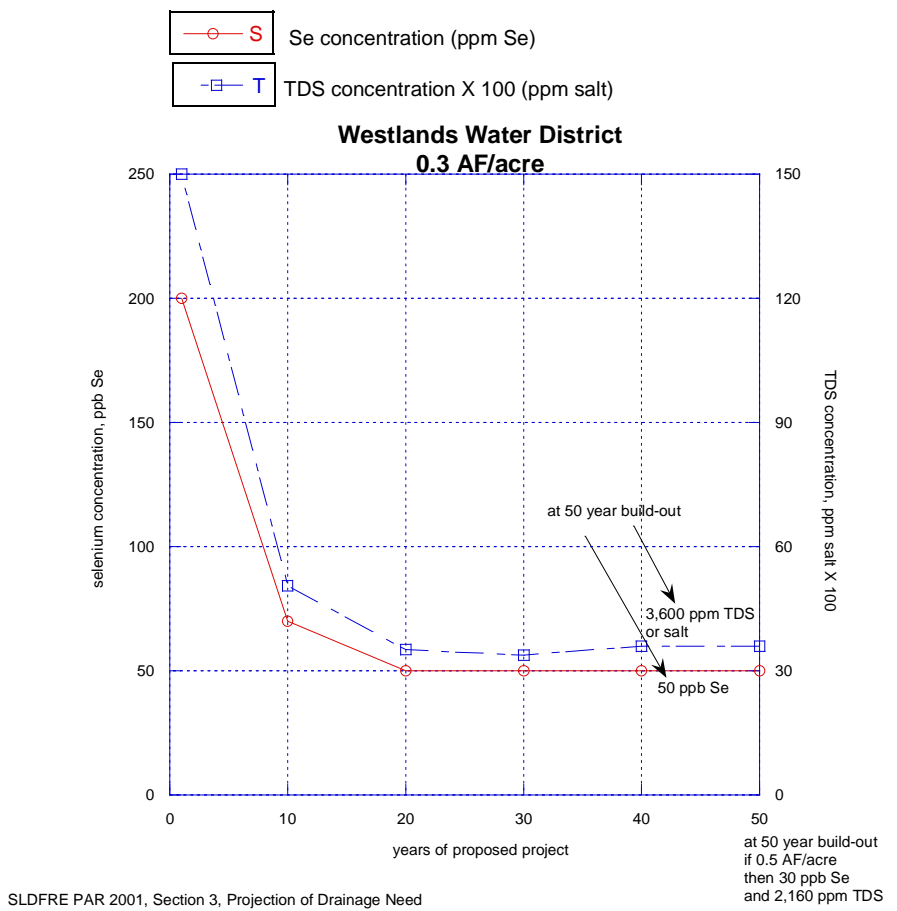

Figure 2. Projection of selenium and salt concentrations (i.e. drainage need) for 1 to 50 years for the Westlands Water District (SLDFRE Planning Alternatives Report, 2001).

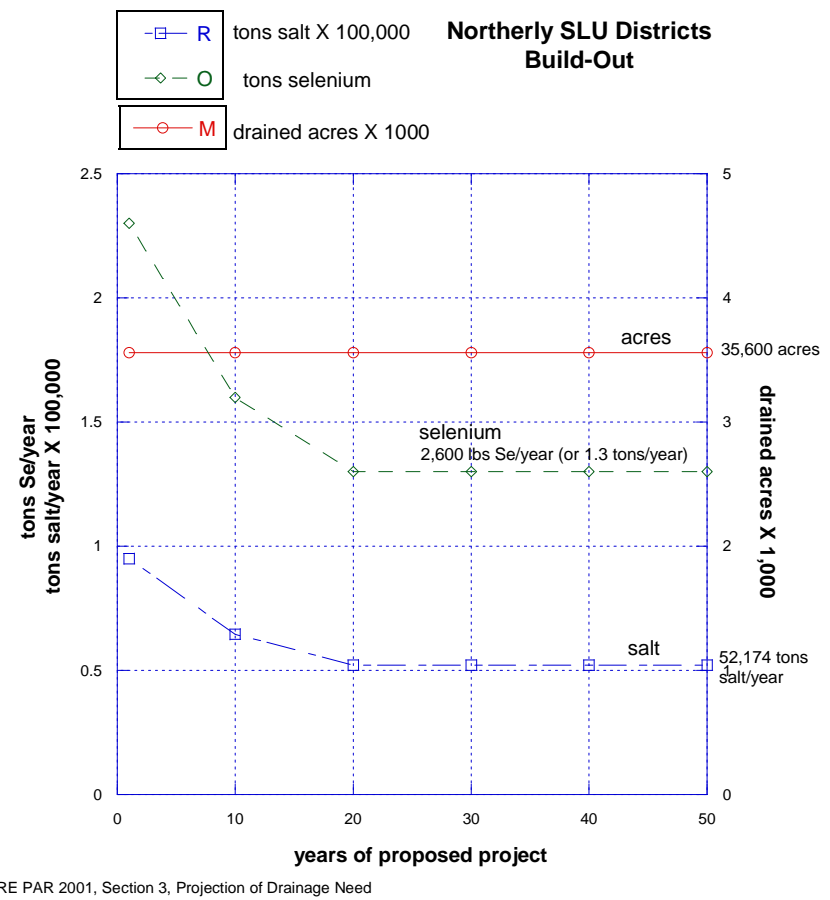

Figure 3. Projection of drained area, selenium loads, and salt loads (i.e. drainage need), for 1 to 50 years for the Northerly San Luis Unit districts (SLDFRE Planning Alternatives Report, 2001). 


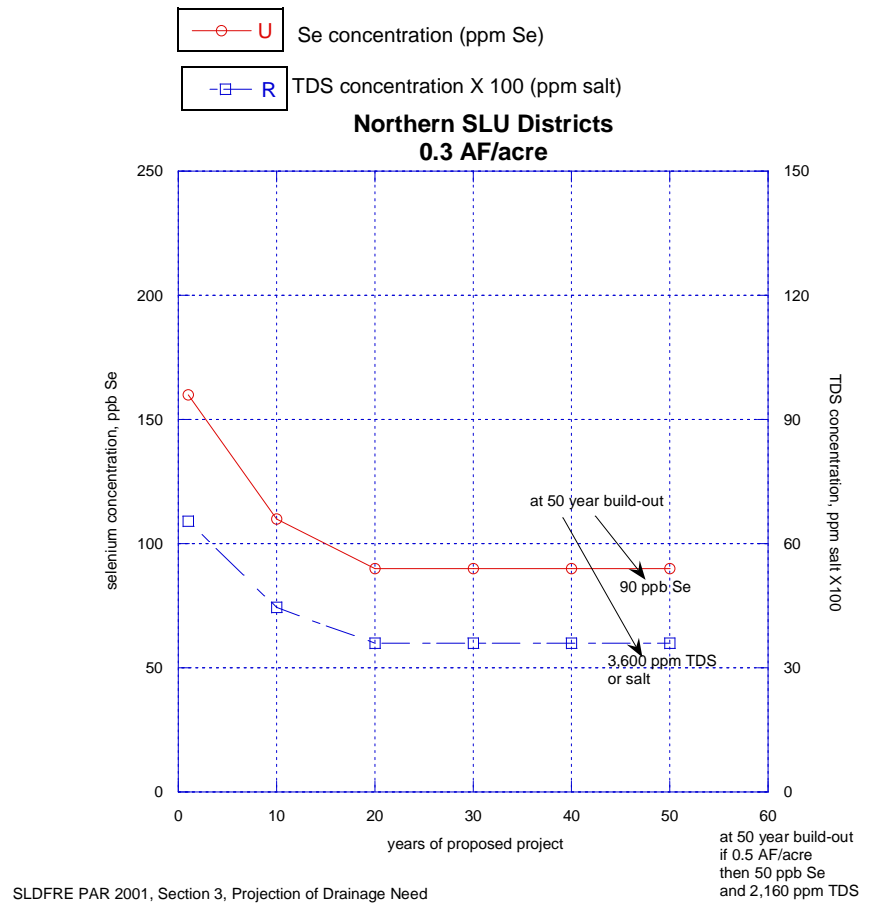

Figure 4. Projection of selenium and salt concentrations (i.e. drainage need) for 1 to 50 years for the Northerly San Luis Unit districts (SLDFRE Planning Alternatives Report, 2001).

\section{Reduction in Applied Water: Land Retirement and Isolation of Selenium}

When lands are retired, there is an overall reduction in water applied to a district. In general, less water applied as irrigation means less drainage produced, which in turn means less drainage requiring treatment and storage. Table 1 shows amounts of drainage reduction in terms of AF/year and AF/acre/year that can be expected given a decrease in the area of land irrigated (SLDFRE EIS, appendix C, simulated 2050 drainflow). The assumption used in the SLDFRE EIS analysis of land retirement for calculating drainage quantity was that the percentage of CVP water contract supply available was 59\%. This percentage differs from the assumption in the water-needs alternative of five districts receiving an average of $70 \%$ of their existing CVP contact amounts.

Table 1. Simulations of drainage produced under different land retirement alternative.

\begin{tabular}{|l|r|r|r|r|r|}
\hline \multicolumn{1}{c}{$\begin{array}{c}\text { Alternative } \\
\text { (acres retired) }\end{array}$} & \multicolumn{1}{c|}{$\begin{array}{c}\text { Westlands } \\
\text { (AF/yr) }\end{array}$} & \multicolumn{1}{c|}{ AFlacre/yr } & \multicolumn{1}{c|}{$\begin{array}{c}\text { Northerly } \\
\text { (AF/yr) }\end{array}$} & \multicolumn{1}{c|}{$\begin{array}{c}\text { AFlacre/yr } \\
\text { (AF/yr) }\end{array}$} \\
\hline Current acres & 40,562 & 0.24 & 41,800 & 0.55 & 82,362 \\
\hline 100,000 acres & 34,811 & 0.25 & 41,800 & 0.55 & 76,611 \\
\hline 200,000 acres & 18,035 & 0.26 & 40,840 & 0.53 & 58,875 \\
\hline 300,000 acres & 0 & 0 & 37,960 & 0.47 & 37,960 \\
\hline
\end{tabular}

Data inputs: SLDFRE EIS, appendix C, simulated 2050 drainflow.

The compilation in table 1 shows separate analyses for the Westlands Area and the Northerly Area. The majority of land retirement is in the Westlands Area, with only nominal retirement in the Northerly Area of 10,000 acres (i.e., Broadview Water District). The range of retired acreage considered in the Westlands Area is from approximately 50,000 acres to 300,000 acres (table 1). 
Irrigation ceases on retired lands and groundwater pumping and surface-water deliveries are discontinued. The pumping rate assumed to continue under actively irrigated lands is 175,000 $\mathrm{AF} /$ year within Westlands Area, an amount equal to average private supply reported in Westlands Water District 2003 Water Needs Assessment. The analysis shows that the amount of drainflow decreases as the amount of acreage retired increases. The rate of drainflow per acre remains practically constant for each alternative at $0.25 \mathrm{AF} /$ acre/year for the Westlands Area under progressively more land retirement. Comparing among options, associated drainflow decreases from 40,562 AF/year to zero AF/year as ultimately all drainage-impaired lands in the Westlands Area are retired. However, several conditions may be inherent in the resultant zero drainflow, namely to achieve this result, a balance of reduced irrigation and land and groundwater pumping is required to not increase or transfer drainage problems. The percent reduction in drainflow is $14 \%$ with increasing retirement by 31,437 acres; $56 \%$ with increasing retirement by 127,859 acres; and $100 \%$ with increasing retirement by 241,097 acres.

The retired acreage considered in the Northerly Area is 10,000 acres (table 1). Drainflow remains essentially constant at 40,000 AF/year. The conditions inherent in achieving this drainflow include shallow-water management, seepage reduction, and drainage recycling. The Northerly Area shows a rate of drainflow almost two-fold higher than that of the Westland Area (0.55 AF/acre/year).

One of the original intents of land retirement as envisioned by the SJVDP was to isolate selenium (SJVDP, 1990a). Recommended criteria for land retirement of irrigated farmlands listed by the SJVDP included retiring lands with poor groundwater quality ( $\geq 50 \mu \mathrm{g} / \mathrm{L}$ selenium) and retiring large contiguous blocks of land. Lands overlying areas of shallow ground water with concentrations of selenium exceeding $200 \mu \mathrm{g} / \mathrm{L}$ were considered special candidates for retirement (i.e., "hotspots"). As irrigation was stopped, selenium was contained as the shallow groundwater table dropped beneath those lands. To some extent, instead of contributing to their contamination, the dewatered area beneath the retired lands would then become a sink to receive contaminated water from adjacent lands. The feasibility of this strategy depended on the existence of shallow groundwater areas in which concentrations of selenium are much greater than those of surrounding areas (see SJVDP, figure 23 for 1990a assessment and SLDFRE Plan Formulation Report Addendum, figure 3-2 for current assessment of selenium concentrations in shallow groundwater). More recent modeling of land retirement strategies shows that not all needs (e.g., drainage reduction, agricultural suitability; creation of habitat) can be served by one strategy (SJVDIP, 1991; Purkey and Wallender, 2001). If the goal is to reduce drainage, then the strategy would be to retire down-gradient water-logged lands. If the goal is to create a sustainable integrated production/habitat system, then up-gradient land retirement emerges as the most logical strategy. Implementation of a successful land retirement program may require an approach that weighs independently the benefits of drainage reduction, selenium reduction, habitat creation, water acquisition and removal of lands that are no longer productive. Such an approach would also serve to identify target lands within each category that might not be considered for land retirement under a voluntary land retirement program. 


\section{Reduction in Applied Water: Source Control}

Tables 2 and 3 show how improved irrigation efficiency would decrease drainflow (or designated here as a more generalized reduction in recharge) (SLDFRE EIS, appendix C, simulated 2050 drainflow).

Table 2. Simulations of drainage produced under moderate recharge reduction.

\begin{tabular}{|l|l|l|l|l|l|}
\hline $\begin{array}{c}\text { Alternative } \\
\text { (acres retired) }\end{array}$ & \multicolumn{1}{|c|}{$\begin{array}{c}\text { Westlands } \\
\text { (AF/yr) }\end{array}$} & \multicolumn{1}{|c|}{ AFlacre/yr } & $\begin{array}{c}\text { Northerly } \\
\text { (AF/yr) }\end{array}$ & AFlacrelyr & Combined (AFlyr) \\
\hline Current acres & 20,647 & 0.18 & 34,160 & 0.42 & 54,807 \\
\hline 100,000 acres & 17,676 & 0.19 & 34,160 & 0.42 & 51,836 \\
\hline 200,000 acres & 9,085 & 0.19 & 33,040 & 0.40 & 42,285 \\
\hline 300,000 acres & 0 & 0 & 31,280 & 0.36 & 31,280 \\
\hline
\end{tabular}

Data inputs: SLDFRE EIS, appendix C, simulated 2050 drainflow.

Table 3. Simulations of drainage produced under maximum recharge reduction.

\begin{tabular}{|l|r|r|r|r|r|}
\hline $\begin{array}{c}\text { Alternative } \\
\text { (acres retired) }\end{array}$ & \multicolumn{1}{c|}{$\begin{array}{c}\text { Westlands } \\
\text { (AF/yr) }\end{array}$} & \multicolumn{1}{c|}{ AFlacre/yr } & \multicolumn{1}{c|}{$\begin{array}{c}\text { Northerly } \\
\text { (AF/yr) }\end{array}$} & \multicolumn{1}{|c|}{ AF/acre/yr } & Combined (AF/yr) \\
\hline Current acres & 13,067 & 0.16 & 26,520 & 0.29 & 39,587 \\
\hline 100,000 acres & 11,038 & 0.16 & 26,520 & 0.29 & 37,558 \\
\hline 200,000 acres & 5,422 & 0.16 & 26,040 & 0.28 & 31,462 \\
\hline 300,000 acres & 0 & 0 & 24,600 & 0.25 & 24,600 \\
\hline
\end{tabular}

Data inputs: SLDFRE EIS, appendix C, simulated 2050 drainflow.

Moderate recharge reduction as applied to current acres and under various land retirement alternatives means improvements in irrigation efficiency would decrease drainflow rates. Maximum recharge reduction as applied to current acres and under various land retirement alternatives means additional improvements in shallow groundwater management, regional recycling, and seepage reduction (i.e., lining water supply canals), would decrease drainflow rates. Modeling efforts in the SLDFRE EIS and supporting documents use various estimates of areas drained (i.e., to install subsurface drains or drain), but most assume that only two-thirds of the areas identified would have on-farm drainage systems and that arability can be maintained under this assumption.

For the Westlands Area, comparison of alternatives in terms of instituting various levels of source control options (current, moderate or maximum) within a land retirement alternative shows drainflow decreases from 40,562 to 13,067 AF/year, with concomitant reduction in AF/tiled acre/year from 0.24 to 0.16 . The percent reduction in drainflow is from $49 \%$ with moderate recharge reduction for a total reduction of $68 \%$ with a maximum recharge reduction. For the Northerly Area under the same sets of alternatives, drainflow decreases from 41,800 to 26,520 AF/year, with a concomitant reduction in $\mathrm{AF} /$ tiled acre/year from approximately 0.50 to 0.28 . The percent reduction in drainflow is from $18 \%$ with moderate recharge reduction for a total reduction of $37 \%$ with a maximum recharge 
reduction. A combined analysis can be more directly compared to data given in recent proposals (refer to later discussion). Overall our analysis shows that much can be done with a program of comprehensive recharge reduction (i.e., in essence, the linking of land retirement, water retirement, on-farm source control, and groundwater pumping options). Retiring of all drainage impaired lands would eliminate the need for drainage service in the Westlands Area. However, drainage management facilities would still be required in the Northerly Area, where land retirement is limited to a nominal 10,000 acres (i.e., Broadview Water District) immediately downslope from the border with Westlands Water District.

\section{Hydrologic Balance: Regional Groundwater Extraction from the Semi-Confined Aquifer}

From a regional perspective, the drainage problem in the western San Joaquin Valley can be seen as a consequence of a hydrologic imbalance: more water is being added to the system than is being removed. Consequently, the water table is rising and there is a need for drainage. This hydrologic imbalance can be partly addressed through a regional program that substitutes groundwater pumping for surface water delivery (SJVDP, 1990a: Belitz et al., 1993). Thus the need for water within a district could be reduced further by the amount of groundwater pumped on adjacent lands to manage ground water levels and achieve hydrologic balance. Groundwater extraction was a strategy that is in the mix of strategies recommended by the SJVDP. Groundwater flow models, both those originally developed by the SJVDP and newly developed models, are available for the Westlands and Northerly Areas to provide the basis for consideration of a groundwater pumping strategy on a regional scale (SJVDP, 1990a; Belitz et al., 1993; Belitz and and Phillips, 1995; Barlow et al., 1996; Brush et al., 2004; 2006).

As noted in the SLDFRE EIS (appendix C), "Although drainwater reduction actions other than the ones selected have been proposed in the Westside Regional Drainage Plan and could be implemented to reduce drainage flows (e.g., shallow groundwater pumping), it was determined that they were either not cost effective compared to disposal facilities, or it was not reasonable to assume that they would be implemented due to the uncertainty regarding effectiveness of action. Shallow groundwater pumping shows promise for reducing drainflows. However, additional information is needed to demonstrate its practical feasibility, including the potential uses for the pumped groundwater." Given these statements and the assumptions used in simulations of drainage produced under different land retirement alternatives for the SLDFRE EIS (tables 2 and 3), there is a need to further understand current and future effects of ground-water pumping program. Specifically, in the SLDFRE EIS, the base-case assumption was 175,000 AF/year of pumping under actively irrigated lands; and in the Groundwater Needs alternative, the water supply included local groundwater supplies of $185,000 \mathrm{AF} /$ year.

A more recent study evaluated the effect of groundwater pumping to achieve an optimization of productive lands with no abandonment due to waterlogging (Barlow et. al., 1996). Belitz and Phillips (1995) proposed a hydro-geologic approach as an alternative to agricultural drains. They also described the expanding problem of bare-soil evaporation (i.e., land typically underlain by a water table between 5 to 7 feet of land surface where water is close enough to the surface to evaporate) that a regional groundwater program could manage:..."maintenance of present practices results in a worsening of the situation: the total area subject to bare-soil evaporation increases from $224 \mathrm{mi}^{2}$ in 1990 to $344 \mathrm{mi}^{2}$ in 2040, and drain flow increases from 25,000 ac ft/yr to 28,000 ac ft/yr. Although land retirement results in elimination of bare-soil evaporation and drain flow in the areas retired, it has little to no effect in adjacent areas. In contrast, regional-scale changes in recharge and pumping are effective for regional management. The area subject to bare-soil evaporation can be reduced to 78 $\mathrm{mi}^{2}$, and drain flow to 8000 ac ft/yr if (1) recharge is reduced by 15\% (26,000 ac ft/yr) in areas that 
currently use surface and groundwater (362 $\left.\mathrm{mi}^{2}\right)$; (2) recharge is reduced by $40 \%$ (28,000 ac ft/yr) in areas that currently use only surface water (137 $\left.\mathrm{mi}^{2}\right)$; and (3) pumping rates are uniformly incremented by $0.5 \mathrm{ft} / \mathrm{yr}(160,000 \mathrm{ac} \mathrm{ft} / \mathrm{yr})$ in both areas. If these water budget changes were to be implemented in the study area, and in adjacent areas with similar hydrogeologic characteristics, then approximately 400,000 ac ft/yr of surface water would be made available. Thus a shift in the hydrologic budget in the central part of the western San Joaquin Valley improves the prospects for sustaining agriculture in the area, and could provide substantial water resources for other uses."

\section{Storage of Concentrated Drainage Water on Land Surface: Mass Balance of Salt and Selenium in Waste Streams}

The SJVDP planned for eventual disposal, storage, or treatment of a limited amount of drainwater (SJVDP, 1990a). Drainage reuse areas were to reduce the volume of drainage requiring ultimate disposal by reusing it on progressively more salt-tolerant crops. The volume reduction would reduce disposal costs and treatment costs, if treatment became necessary. The volume of water was reduced by plant evapo-transpiration, with dissolved constituents becoming more concentrated and potentially easier to manage. Seepage to groundwater aquifers also would potentially reduce volume, but further contaminates specific aquifers. Drainage water captured in the tile drainage system under these lands would be collected and pumped into local distribution centers to become a source for irrigation of progressively more salt-tolerant crops. In terms of eventual storage, the SJVDP recommended some evaporation ponds in some areas that were to be highly managed to be bird free. Mitigation of evaporation ponds with clean habitat also was necessary.

The recently proposed reuse areas present opportunities for wildlife use and selenium exposure. Potential use of regulating ponds to help control flow as a part of the engineered reuse system and ponding during flood events in the treatment areas also may create a potential wildlife exposure risk similar to those originally realized at Kesterson National Wildlife Refuge (Presser and Ohlendorf, 1987). Selenium toxicity concerns in these areas and habitats are considered below (refer to Ecological Risk of Selenium).

Components of the sequential waste-stream for the in-valley alternatives in the SLDFRE EIS and for the current proposal are (figure 5):

- drainwater collection and conveyance systems, including the Delta-Mendota Canal Drain;

- reuse facilities

- reuse pumping stations to convey drainwater to treatment facilities

- reverse osmosis (RO) treatment facilities

- selenium bio-treatment facilities; and

- evaporation ponds in EIS planning or enhanced solar evaporators in recent planning. 


\section{Facilities}

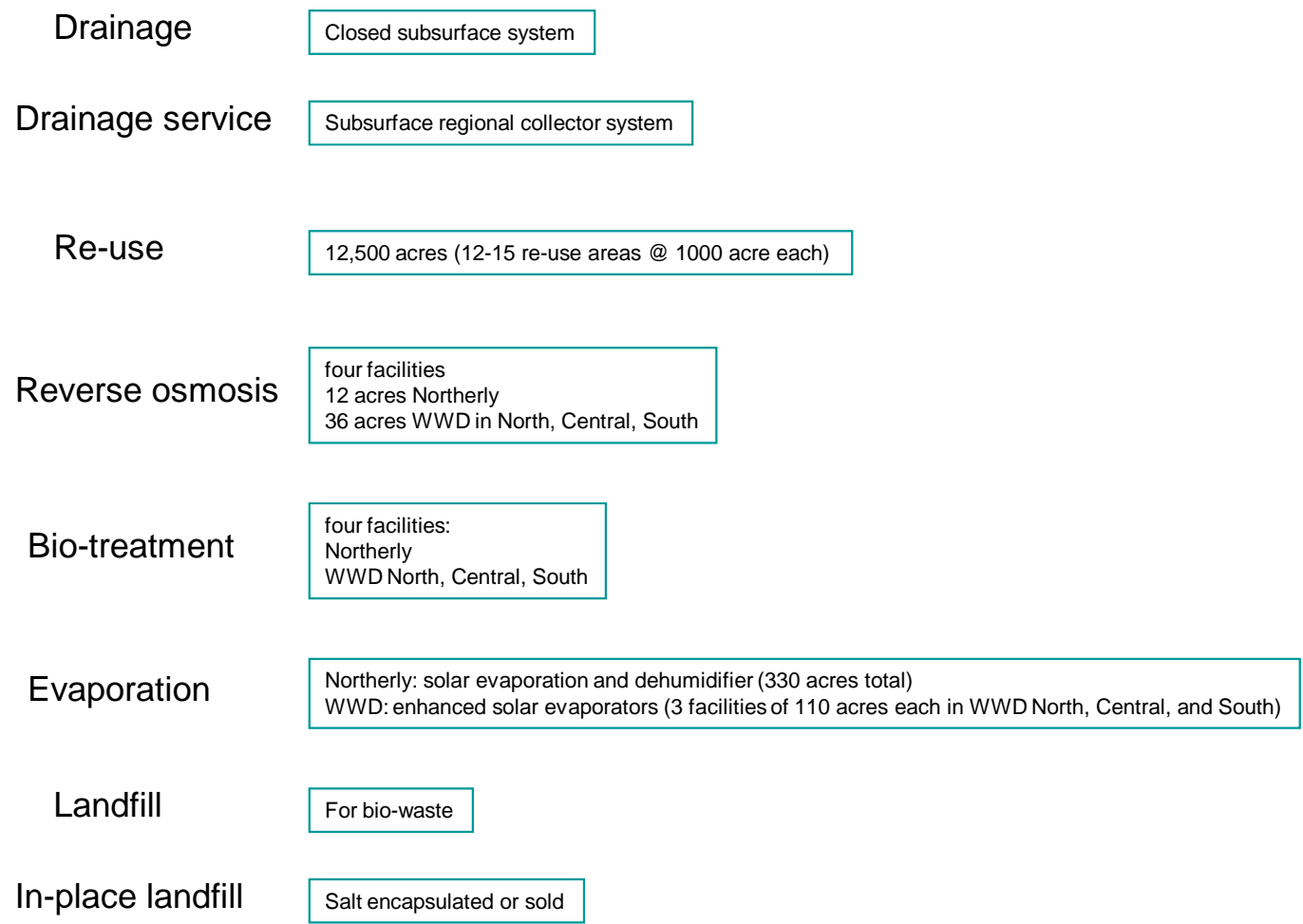

Figure 5. Components of sequential waste-stream for recently proposed in-valley drainage management plan.

The draining of accumulated reservoirs of salt and selenium stored in the soils and aquifers of the valley to surface impoundment may have large-scale implications for the future of the valley in terms of tradeoffs of contaminated groundwater aquifers (i.e., life of the aquifer for irrigation and drinking water use) for contaminated land-surfaces (i.e., creation of salt waste dumps and landfills for designated bio-treatment waste). A selenium mass balance analysis quantifies the amount of selenium, in general, exposed on the landscape, and specifically, contained in each waste-stream component (e.g., regional collector, reuse area, reverse osmosis facility, selenium bio-treatment plant, and enhanced solar evaporator system - figures 6 through 12). Data used in deriving the selenium mass balance are compiled from SLDFRE Draft EIS, 2005, appendix C, table C5; SLDFRE EIS, 2006, section 2, Table 2.13-1; SLDFRE Plan Formulation Report Addendum, 2004, page 4-29; USFWS Conceptual Monitoring, Compliance, and Adaptive Management Plan, 2/28/08 draft; USBR Handout \#4, San Luis Unit Drainage Implementation Plan, 2/12/08.

In the SLDFRE EIS alternatives and in the recently proposed plan, selenium concentrations in drainflow increase through each step until the selenium bio-treatment step, in which the selenium concentration in the evaporated brine is reduced to $10 \mu \mathrm{g} / \mathrm{L}$. Alternatives in the SLDFRE EIS originally showed evaporation ponds (water-column selenium regulatory requirement of $<2 \mu \mathrm{g} / \mathrm{L}$ ) as the final reduction and storage step, but recent proposals have eliminated evaporated ponds and substituted enhanced solar evaporation as the final waste-stream step. Although the amounts discharged at the end of the waste-stream are not affected by this decision, the recently stated goal of 
$10 \mu \mathrm{g} / \mathrm{L}$ for the evaporated brine is not discussed in terms of regulatory requirements to protect wildlife and human health (e.g., from aerosol spray drift or airborne particulate salt and selenium associated with enhanced solar technology). Additionally, EIS planning shows some drainflow from the reuse areas going directly to the selenium bio-treatment facility, while other variations show only drainflow from RO going to the selenium bio-treatment facility. This evolution in planning is important to the feasibility of selenium bio-treatment because of the reduction in efficiency or nonperformance expected as salt concentrations increase (measured in this case as TDS, Total Dissolved Solids). Drainage from a re-use with a TDS of 4,000 to $8,000 \mathrm{mg} / \mathrm{L}$ is more easily treated than drainage from a RO facility with a predicted TDS of $32,520 \mathrm{mg} / 1 \mathrm{TDS}$ (refer to later discussion).

The selenium bio-treatment also includes a chemical reduction step to change the oxidation state and bioavailability of selenium in the final waste product. The concern addressed by this additional step is that bio-treatment, while causing a decrease in the concentration of selenium, also may cause a change in the form of selenium to a more bioavailable organic form of selenium that raises the overall bioaccumlative potential of the waste stream (SLDRE EIS, 2007, appendix B).

The stream of RO treated water produced would be available for other uses, but some waterquality issues (e.g., boron and mercury) remain for the product water. For example for planning for agricultural use of RO product water, it would be necessary to dilute the concentration of boron in the product water by up to 36-fold with CVP water to obtain a boron concentration that would not impair plant growth (SLDFRE EIS, 2007, Response to Comments).

The mass balance analysis also helps in consideration of the magnitude of mitigation for potential adverse impacts due to contaminant build-up, exposure to concentrated drainage wastestreams, and exposure to potential aerial dispersion of liquids and particulates. In addition to dedicated mitigation, buffer zones to moderate contamination have been suggested. As in the SJVDP strategies, successful mitigation may depend on identifying a dedicated source of water for such offsets.

For comparison to projected selenium loads given here, the historical annual discharge from the Westlands subarea via the San Luis Drain was 4,776 lbs selenium, with a total of 17,400 lbs selenium discharged to Kesterson National Wildlife Refuge over the history of San Luis Drain usage (January 1981 to September 1985). The cumulative 17,400 lbs selenium is termed as one kesterson (kst). The use of this unit provides perspective on the mass of selenium that was a hazard to wildlife when released directly to a wetland (Presser and Piper, 1998).

Figures 6 to 12 show conceptual diagrams annotated with drainage volumes, selenium concentrations, and selenium loads for the sequence of steps in a drainage waste-stream. Tables 4 and 5 show compiled data in tabular form for comparison amongst alternatives. These mass balance illustrations for the SLDFRE EIS land retirement alternatives and the recently proposed drainage management plans are conceptualized with solar sprinkler evaporators as the terminal technology to incorporate the latest concepts on storing and concentrating drainage and to facilitate comparison amongst alternatives. As noted before, the amounts discharged at the end of the waste-stream are not affected by this decision to substitute evaporators for ponds. 


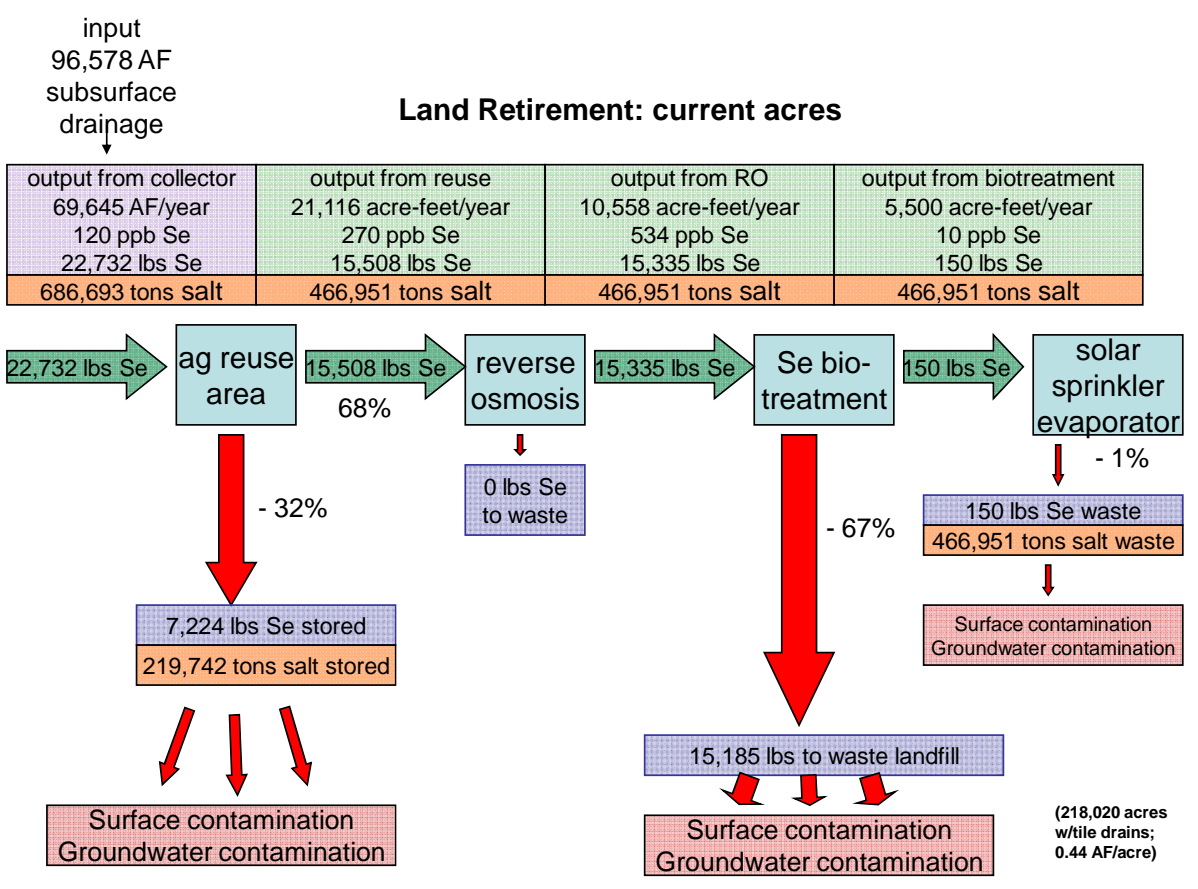

Figure 6. Selenium and salt mass balance for SLDFRE EIS in-valley alternative with current acres retired (combined Westlands Area and Northerly Area).

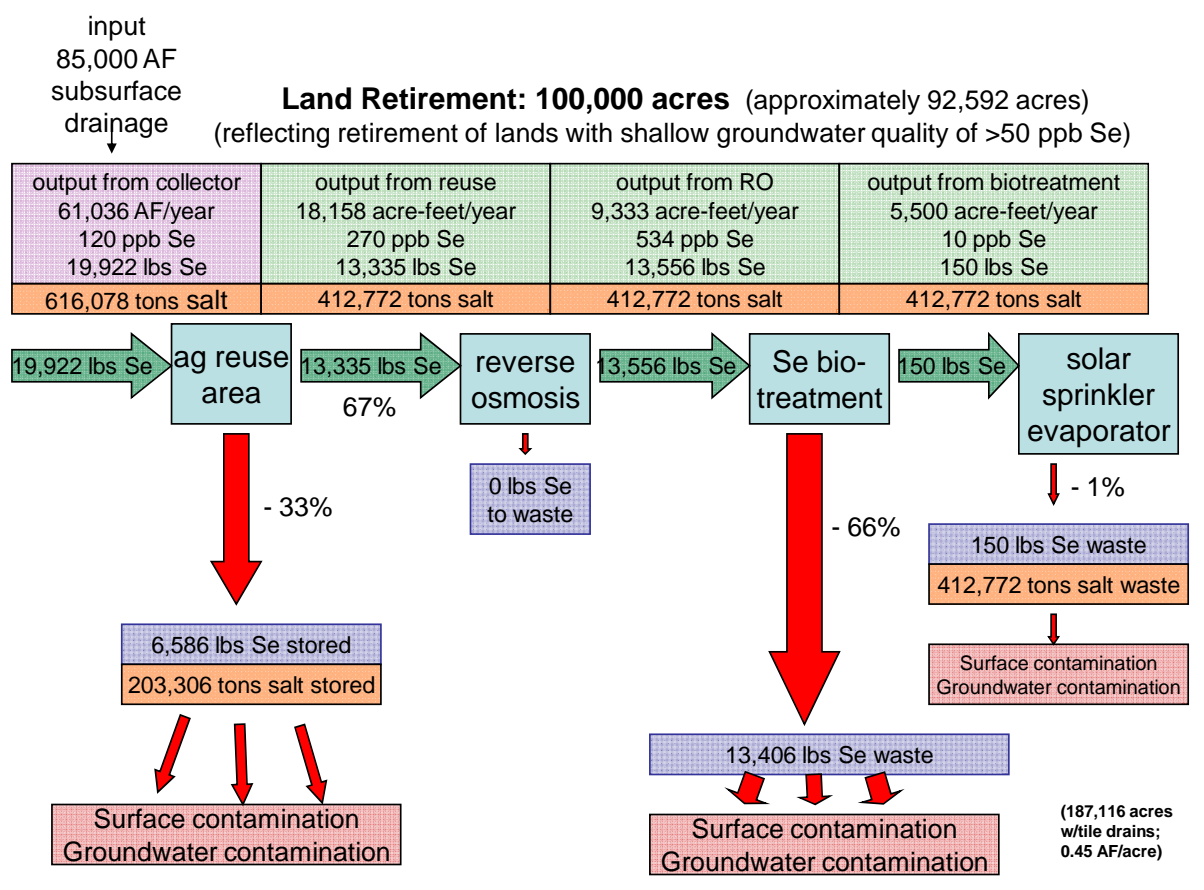

Figure 7. Selenium and salt mass balance for SLDFRE EIS in-valley/groundwater quality land retirement alternative with 100,000 acres retired (combined Westlands Area and Northerly Area). 


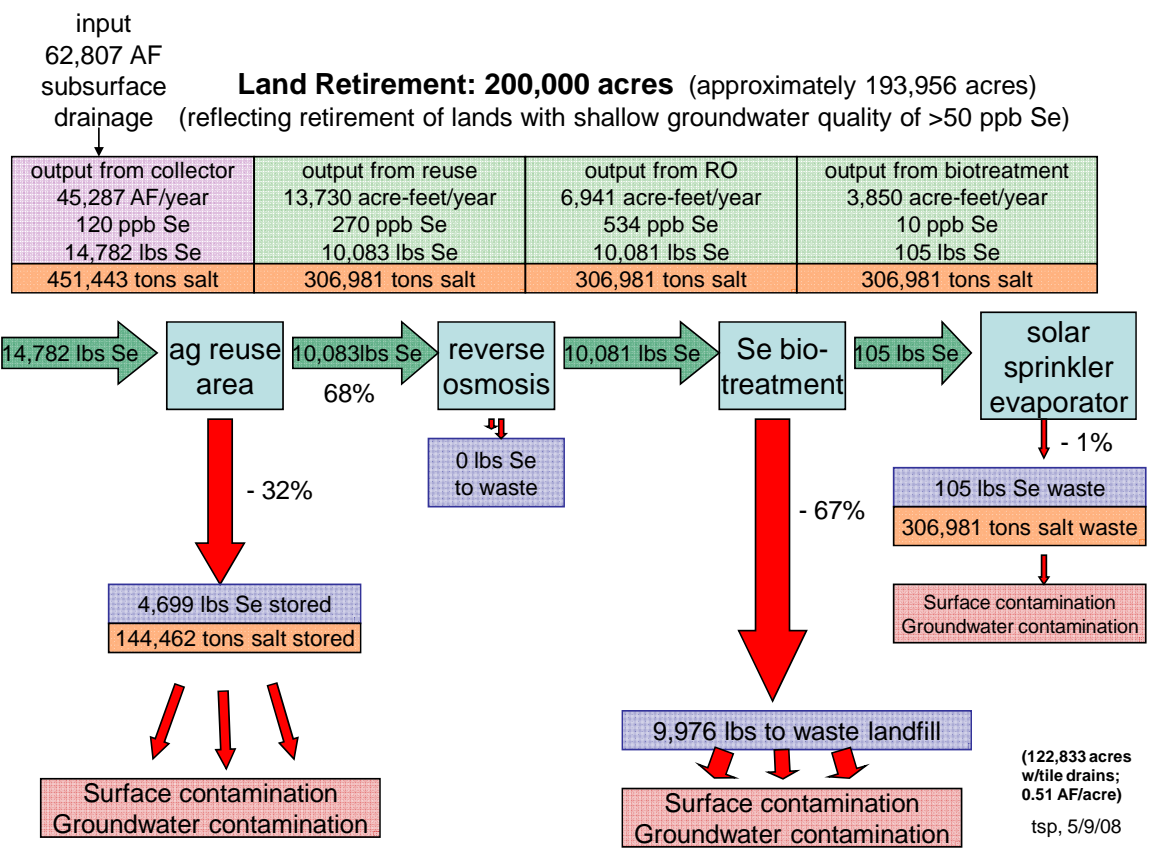

Figure 8. Selenium and salt mass balance for SLDFRE EIS in-valley/water needs land retirement alternative with 200,000 acres retired (combined Westlands Area and Northerly Area).

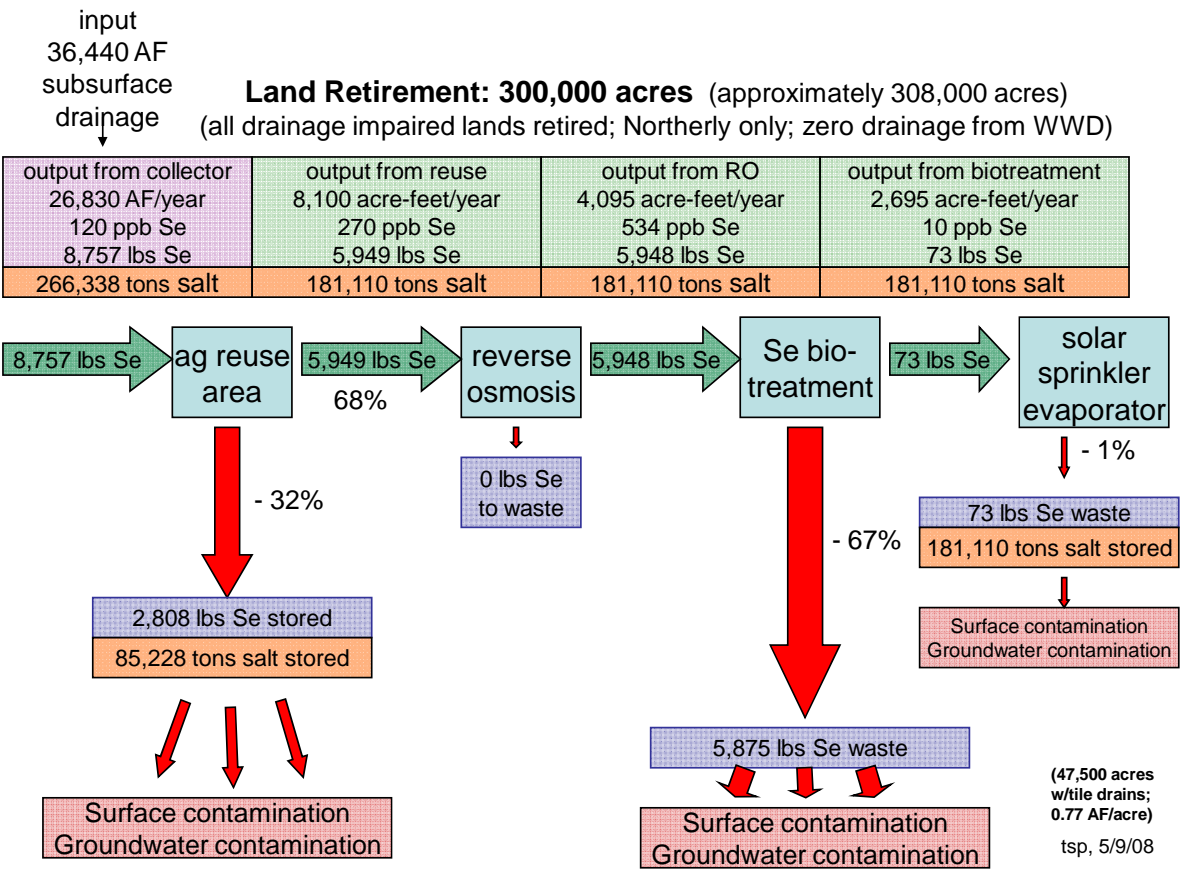

Figure 9. Selenium and salt mass balance for SLDFRE EIS in-valley/drainage-impaired lands land retirement alternative with 300,000 acres retired (combined Westlands Area and Northerly Area). 


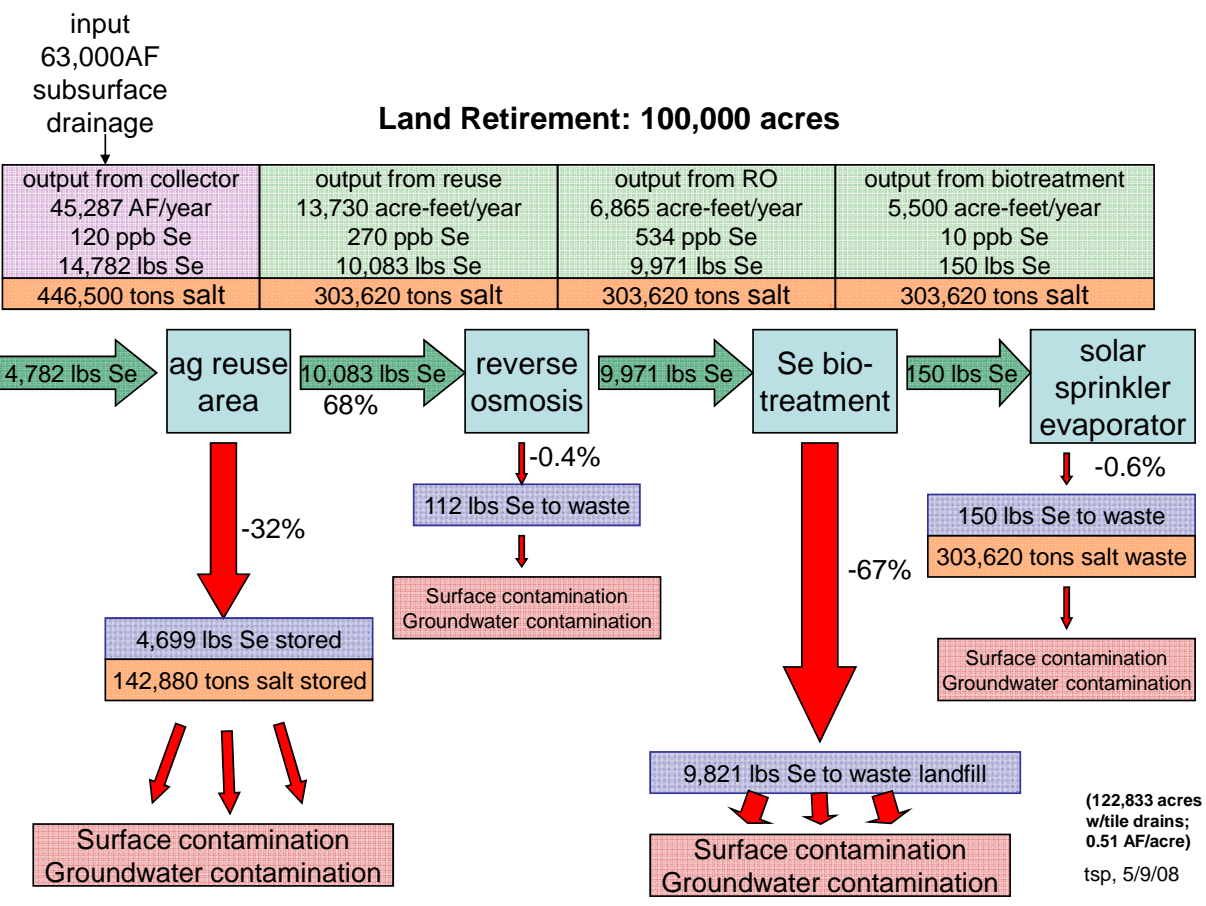

Figure 10. Selenium and salt mass balance for recently proposed in-valley management plan with 100,000 acres retired (combined Westlands Area and Northerly Area).

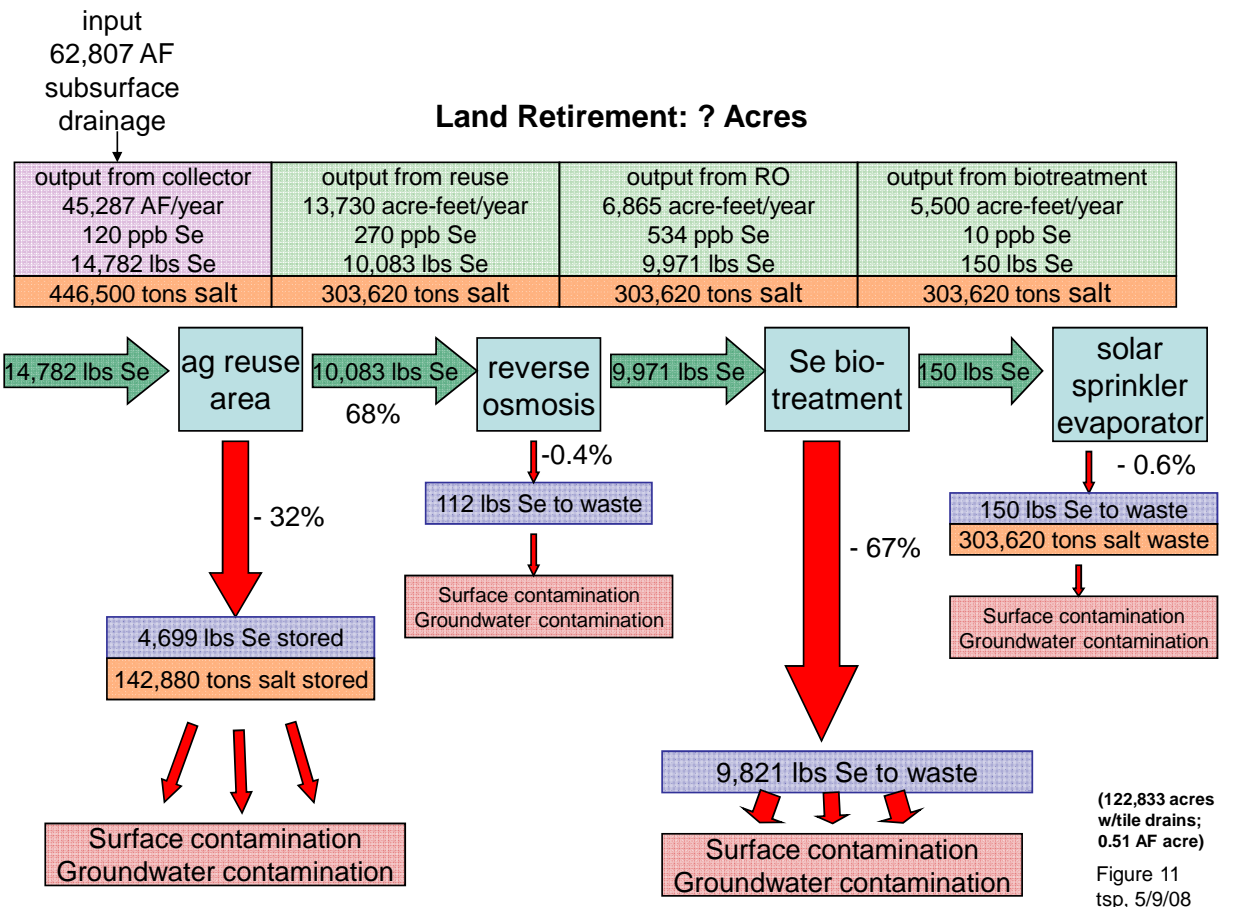

Figure 11. Selenium and salt mass balance for a variation of recently proposed in-valley management plan (combined Westlands Area and Northerly Area; Westlands Area at full capacity). 


\section{Land Retirement: theoretical scenario}

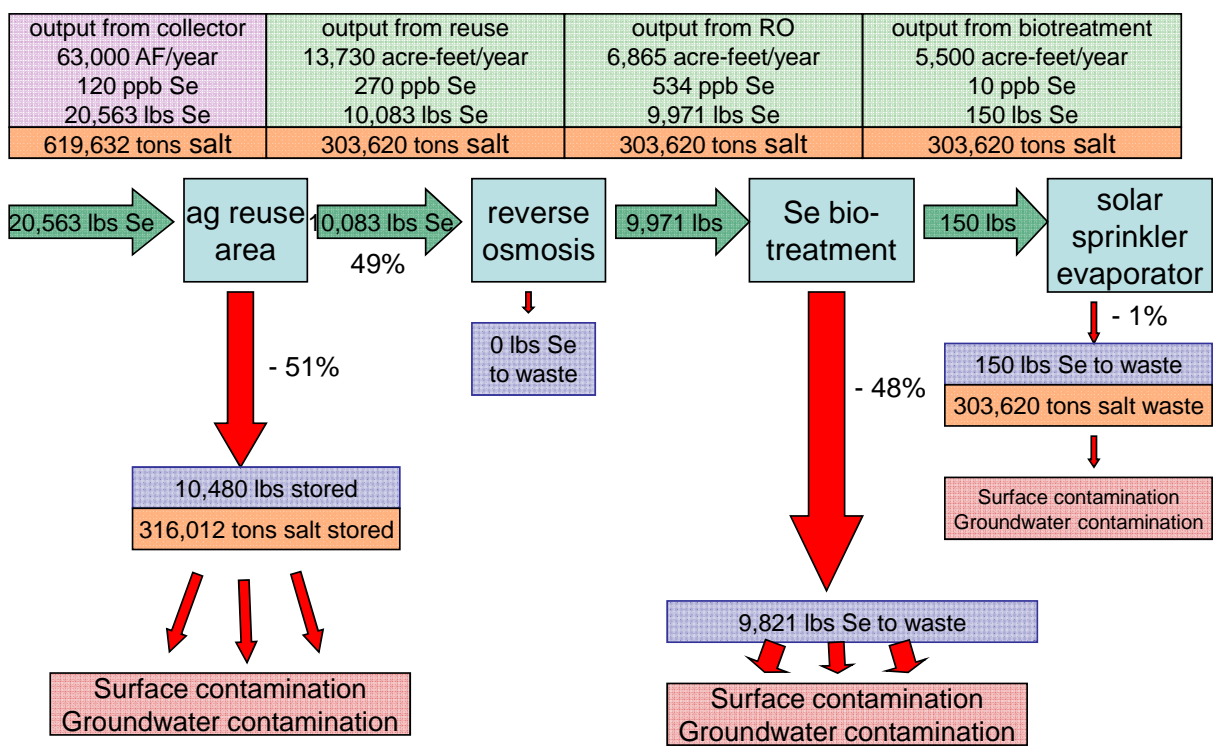

Figure 12. Selenium and salt mass balance for theoretical in-valley alternative with equal proportion of drainage stored in reuse as that processed through waste-stream to reverse osmosis, bio-treatment, and enhanced solar evaporation (combined Westlands Area and Northerly Area). 
Table 4. Selenium (Se) mass balance for land retirement alternatives; data is per year; for 50 year project, multiple by 50.

\begin{tabular}{|c|c|c|c|c|c|c|c|c|c|c|c|c|c|c|}
\hline $\begin{array}{l}\text { land } \\
\text { retirement } \\
\text { alternative }\end{array}$ & $\begin{array}{c}\text { planned } \\
\text { retired } \\
\text { acres/ } \\
\text { nominal } \\
\text { acres in } \\
\text { scenarios }\end{array}$ & $\begin{array}{c}\text { subsurface } \\
\text { drainage/ } \\
\text { regional } \\
\text { drainage } \\
\text { input } \\
\text { (AF/yr) }\end{array}$ & $\begin{array}{c}\text { regional } \\
\text { drainage } \\
\text { collector } \\
\text { output/re- } \\
\text { use input } \\
\text { (AF/yr) }\end{array}$ & $\begin{array}{c}\text { planned } \\
(\mu \mathrm{g} / \mathrm{L} \\
\mathrm{Se})\end{array}$ & $\begin{array}{l}\text { calculated } \\
\text { load (lbs } \\
\text { Se/yr) }\end{array}$ & $\begin{array}{c}\text { reuse } \\
\text { output/ } \\
\text { RO input } \\
\text { (AF/yr) }\end{array}$ & $\begin{array}{c}\text { planned } \\
(\mu \mathrm{g} / \mathrm{L} \\
\mathrm{Se})\end{array}$ & $\begin{array}{c}\text { calculated } \\
\text { load (lbs } \\
\text { Se/yr) }\end{array}$ & $\begin{array}{c}\text { RO } \\
\text { output/ } \\
\text { biotreat- } \\
\text { ment } \\
\text { input } \\
\text { (AF/yr) }\end{array}$ & $\begin{array}{c}\text { planned } \\
(\mu \mathrm{g} / \mathrm{L} \\
\mathrm{Se})\end{array}$ & $\begin{array}{c}\text { calculated } \\
\text { load (lbs } \\
\text { Se/yr) }\end{array}$ & $\begin{array}{c}\text { biotreat- } \\
\text { ment } \\
\text { output/ } \\
\text { input to } \\
\text { solar } \\
\text { (AFlyr) }\end{array}$ & $\begin{array}{c}\text { planned } \\
(\mu \mathrm{g} / \mathrm{L} \\
\mathrm{Se})\end{array}$ & $\begin{array}{c}\text { calculated } \\
\text { load (lbs } \\
\text { Se/yr) }\end{array}$ \\
\hline $\begin{array}{l}\text { Groundwater } \\
\text { Quality }\end{array}$ & $\begin{array}{l}92,592 / \\
100,000\end{array}$ & 85,000 & 61,036 & 120 & 19,922 & 18,158 & 270 & 13,335 & 9,333 & 534 & 13,556 & 5,500 & 10 & 150 \\
\hline Water Needs & $\begin{array}{l}193,956 / \\
200,000\end{array}$ & 62,807 & 45,287 & 120 & 14,782 & 13,730 & 270 & 10,083 & 6,941 & 534 & 10,081 & 3,850 & 10 & 105 \\
\hline $\begin{array}{l}\text { Drainage- } \\
\text { Impaired } \\
\text { Lands }\end{array}$ & $\begin{array}{l}308,000 / \\
300,000\end{array}$ & 36,440 & 26,830 & 120 & 8,757 & 8,100 & 270 & 5,949 & 4,095 & 534 & 5,948 & 2,695 & 10 & 73 \\
\hline $\begin{array}{l}\text { Proposed in } \\
\text { Monitoring } \\
\text { Plan, 2/28/08 }\end{array}$ & 100,000 & 63,000 & $\begin{array}{l}? \\
45,287 *\end{array}$ & 120 & 14,782 & 13,730 & 270 & 10,083 & 6,865 & 534 & 9,971 & 5,500 & 10 & 150 \\
\hline $\begin{array}{l}\text { Proposed in } \\
\text { USBR } \\
\text { handout \#4, } \\
3 / 12 / 08\end{array}$ & $?$ & 62,807 & $\begin{array}{l}? \\
45,287^{*}\end{array}$ & 120 & 14,782 & 13,730 & 270 & 10,083 & 6,865 & 534 & 9,971 & 5,500 & 10 & 150 \\
\hline
\end{tabular}

* assumed from above from Water Needs alternative. Data inputs: Drainwater Quantity and Quality, Appendix C, Draft SLDFR EIS, Table C1-5; Comparison of Features and Specifications, All Disposal Options, SLDFRE EIS, Section 2, Table 2.13-1; Drainage Quantity and Quality and Drainwater Reduction, Section 4 , SLDFRE PFR, 2004, Addendum, page 4-29; USFWS Monitoring Plan, 2/28/08, for proposed drainage management; USBR Handout \#4, 3/12/08. 
Table 5. Selenium (Se) mass balance for Land Retirement Alternatives: calculated storage. Data is per year; for 50 -year project, multiple by 50.

\begin{tabular}{|c|c|c|c|c|c|c|c|c|c|c|}
\hline $\begin{array}{l}\text { land retirement } \\
\text { alternative }\end{array}$ & $\begin{array}{l}\text { planned } \\
\text { retired } \\
\text { acresl } \\
\text { nominal } \\
\text { acres in } \\
\text { scenarios }\end{array}$ & $\begin{array}{l}\text { regional drainage } \\
\text { collector output/ } \\
\text { re-use input } \\
\text { (calculated lbs } \\
\text { Selyr) }\end{array}$ & $\begin{array}{c}\text { storage at } \\
\text { reuse area } \\
\text { (calculated lbs } \\
\text { Selyr) }\end{array}$ & $\begin{array}{l}\text { \%lbs Se } \\
\text { storage in } \\
\text { reuse area }\end{array}$ & $\begin{array}{c}\text { reuse output/ } \\
\text { RO input } \\
\text { (calculated lbs } \\
\text { Se/yr) }\end{array}$ & $\begin{array}{c}\text { \% lbs Se } \\
\text { in RO } \\
\text { waste to } \\
\text { landfill }\end{array}$ & $\begin{array}{c}\text { RO outputl } \\
\text { biotreatment } \\
\text { input (calculated } \\
\text { lbs Se/yr) }\end{array}$ & $\begin{array}{l}\text { \% lbs Se in } \\
\text { biotreatment } \\
\text { waste to } \\
\text { landfill }\end{array}$ & $\begin{array}{c}\text { biotreatment } \\
\text { output/ } \\
\text { input to solar } \\
\text { (calculated lbs } \\
\text { Se/yr) }\end{array}$ & $\begin{array}{c}\text { \% lbs Se } \\
\text { in solar } \\
\text { evapo- } \\
\text { rator }\end{array}$ \\
\hline $\begin{array}{l}\text { Groundwater } \\
\text { Quality }\end{array}$ & $\begin{array}{l}92,592 / \\
100,000\end{array}$ & 19,922 & 6,586 & 33 & 13,335 & 0 & 13,556 & 66 & 150 & 1 \\
\hline Water Needs & $\begin{array}{l}193,956 / \\
200,000\end{array}$ & 14,782 & 4,699 & 32 & 10,083 & 0 & 10,081 & 67 & 105 & 1 \\
\hline $\begin{array}{l}\text { Drainage- } \\
\text { Impaired } \\
\text { Lands }\end{array}$ & $\begin{array}{l}308,000 / \\
300,000\end{array}$ & 8,757 & 2,808 & 32 & 5,949 & 0 & 5,948 & 67 & 73 & 1 \\
\hline $\begin{array}{l}\text { Proposed in } \\
\text { Monitoring } \\
\text { Plan, 2/28/08 }\end{array}$ & 100,000 & 14,782 & 4,699 & 32 & 10,083 & 0.4 & 9,971 & 67 & 150 & 0.6 \\
\hline $\begin{array}{l}\text { Proposed in } \\
\text { USBR handout } \\
\# 4,3 / 12 / 08\end{array}$ & ? & 14,782 & 4,699 & 32 & 10,083 & 0.4 & 9,971 & 67 & 150 & 0.6 \\
\hline
\end{tabular}

Data inputs: same as those for table 4. 
Our analysis includes four land retirement alternatives (figures 6-9): In-Valley alternative (current retired acres); Groundwater Quality alternative (100,000 acres retired); Water Needs alternative (200,000 acres retired); and Drainage-Impaired Area alternative (300,000 acres retired). In these EISderived alternatives, the proportion of selenium stored on the surface to that stored in a dedicated landfill was assumed not to vary by alternative (i.e., a constant $33 \%$ to reuse and $67 \%$ to waste-stream). Figures 10-11 show recent proposed alternatives of land retirement. Figure 12 shows a theoretical alternative that varies the proportion of drainage to reuse and to waste-stream (essentially a 50:50 proportion of stored in reuse areas to treatment and disposal). All representations and calculations presume successful treatment is accomplished, thus these figures depict the most favorable outcomes possible. Note also that in recent proposals versions, the amount of subsurface drainage produced (about 63,000 AF/year at the subsurface drain stage and 45,000 AF/year after a series of on-farm and regional measures are instituted) is similar to that shown for the Water Needs land retirement alternative, but the amount of land retirement varies from 200,000 acres to 100,000 acres or less (table 4).

The land retirement alternatives differ in the amount of selenium brought to the surface for treatment and storage. The initial volume of drainage shown is assumed to be reduced through on-farm activities such as shallow groundwater management, seepage reduction, and recycling. The output selenium concentration from the regional collector is planned to be $120 \mu \mathrm{g} / \mathrm{L}$. For the Groundwater Quality alternative, the Water Needs alternative, and the recently proposed alternative, 14,782 lbs selenium/year enter the series of treatment steps based on planned volumes. For the Drainage-Impaired Area alternative, zero lbs selenium enter the system from the Westlands Area and 8,757 lbs selenium/year enter the system from the Northerly Area. Passage through the reuse area increases the selenium concentration approximately two-fold to $270 \mu \mathrm{g} / \mathrm{L}$, as the waste-stream is further concentrated. Approximately $33 \%$ of the selenium mass (4,699 to 6,586 lbs selenium/year) remains at the reuse areas. $\mathrm{RO}$ treatment again increases the selenium concentration two-fold to $534 \mu \mathrm{g} / \mathrm{L}$. Little selenium is lost to RO waste (less than 1\% or approximately $100 \mathrm{lbs}$ selenium/year) and the majority of selenium proceeds to bio-treatment. With bio-treatment, the selenium concentration is reduced approximately 50-fold to $10 \mu \mathrm{g} / \mathrm{L}$ and 13,556 to $5,948 \mathrm{lbs}$ selenium/year is collected as bio-waste for disposal in landfills or other alternative method of final disposition such as encapsulation in-place. Only 73-105 lbs selenium/year is treated to enhanced solar evaporation. Thus, the majority of selenium is in the bio-waste and not in the evaporated salt component if bio-treatment is successful.

In terms of salt, 616,078 to 266,338 tons salt/year enter the waste-stream in the illustrated scenarios. Approximately $33 \%$ of the total salt mass $(85,228$ to 203,306 tons salt /year) remains at the reuse areas. The TDS concentration of the drainwater is $32,520 \mathrm{mg} / \mathrm{L}$ as it is discharged from the RO step and enters the selenium bio-treatment step. Approximately $67 \%$ of the salt remains to be evaporated by the enhanced solar evaporation systems (181,110 to 412,772 tons salt/year) (figures 612).

At the build-out of the project after 50 years, a cumulative total of 996,100 lbs selenium and 30.8 million tons salt will be discharged under the Groundwater Quality alternative (approximately 100,000 acres retired). Selenium stored in surface reuse areas is estimated at 329,300 lbs/50 years, with salt storage in surface reuse areas at 10.2 million tons $/ 50$ years. Selenium in bio-waste is estimated at $670,300 \mathrm{lbs} / 50$ years, with salt storage at final disposition to landfill at 20.6 million tons $/ 50$ years. The project is designed to be at maximum capacity after 50 years and discharge may continue at that rate into perpetuity given the massive nature of the reservoirs of salt and selenium available for discharge. 


\section{Ecological Risk of Selenium: integration of habitat areas in scaled-up reuse areas and enhanced evaporation systems}

Reuse areas are a crucial part of the proposed management plan and would be areas where integration with terrestrial habitats would take place. Planned reuse areas for the EIS in-valley alternatives range from 7,500 to 19,000 acres. This would represent up to a 10-fold scale-up from the existing pilot project of 1,800 acres. Additional concern is for ponding and creation of transitory aquatic habitats contaminated with selenium in reuse areas as part of management actions for maintaining flow and during rainfall events.

A summary of data from the Panoche Drainage District reuse area in 2004 includes selenium concentrations in bird eggs collected from an accidentally flooded pasture within the reuse area (table 6). Here, concentrated agricultural drainage (60 to $200 \mu \mathrm{g} / \mathrm{L}$ selenium) is being managed to reduce the amount of selenium discharged to the San Joaquin River. The reuse area of 1,800 acres is eventually planned to encompass 4,000 acres. Over 42 species of birds have been found to use this drainwater reuse pilot area. The average selenium concentration in avocet and stilt eggs was $58 \mu \mathrm{g} / \mathrm{g}$ dry weight, which exceeds the threshold for substantive risk (high risk, $>10 \mu \mathrm{g} / \mathrm{g}$ selenium) by approximately 6fold. A reduction of hatchability and deformities of bird embryos would likely occur at these concentrations (USDOI, 1998; Skorupa, 1998). This accidental flooding event illustrates how small ponds are very inviting to aquatic birds of the valley because of already limited habitat opportunities. The timing of appearance of food webs in the ponds and immediate nesting also illustrates the need for vigilance on the part of management for this type of habitat. Concern is also warranted because selenium concentrations in bird eggs from the majority of reference site sampled were also above the high risk threshold (table 6), suggesting a landscape effect larger than the reuse area as management and storage of concentrated drainwater takes place over several years.

Table 6. Average egg selenium concentrations ( $\mu \mathrm{g} / \mathrm{g}$, dry weight) for bird eggs collected in April, May, and June, 2003 from the Panoche Drainage District reuse area $(n=$ number of eggs).

\begin{tabular}{|l|c|c|c|c|c|}
\hline & stilt & Avocet & (stilt and avocet) & killdeer & blackbird \\
\hline Flooded Project & $\begin{array}{c}46.6 \\
(5)\end{array}$ & $\begin{array}{c}68.6 \\
(9)\end{array}$ & $\begin{array}{c}60.8 \\
(14)\end{array}$ & $\begin{array}{c}15.3 \\
(11)\end{array}$ & \\
\hline Rest-of-project & $\begin{array}{c}19.9 \\
(4)\end{array}$ & $\begin{array}{c}12.2 \\
(2)\end{array}$ & $\begin{array}{c}17.3 \\
(6)\end{array}$ & $\begin{array}{c}11.4 \\
(9)\end{array}$ & \\
\hline Rice Fields Reference & 5.4 & ---- & 5.4 & 4.1 & \\
& $(10)$ & $(0)$ & $(10)$ & $(9)$ & \\
\hline Project Reference (excluding rice field & 25.3 & 10.6 & 18.4 & 4.4 & $(11)$ \\
data) & $(6)$ & $(4)$ & $(10)$ & 13.4 & 6.1 \\
\hline Project (total) & 33.2 & 40.4 & 47.7 & $(20)$ & $(20)$ \\
\hline Reference (total) & $(9)$ & $(11)$ & $(20)$ & 4.25 & 5.4 \\
& 15.0 & 10.6 & 12.4 & $(20)$ & $(20)$ \\
\hline
\end{tabular}


Table 7. Range of egg selenium concentrations ( $\mu \mathrm{g} / \mathrm{g}$, dry weight) for bird eggs collected from 2003 through 2006 from the Panoche Drainage District reuse area.

\begin{tabular}{|l|c|c|c|c|}
\hline \multicolumn{1}{|c|}{ species } & $\mathbf{2 0 0 3}$ & $\mathbf{2 0 0 4}$ & $\mathbf{2 0 0 5}$ & $\mathbf{2 0 0 6}$ \\
\hline killdeer & $5.8-33.5$ & $2.79-31.3$ & $6.9-32.2$ & $4.37-54.7$ \\
\hline recurvirostrids (avocets and stilts) & $9.8-98.9$ & $7.53-48.7$ & $22.6-45.7$ & $3.39-95.1$ \\
\hline red-winged blackbirds & $4.5-11.0$ & $4.79-7.26$ & N/A & $5.54-15.9$ \\
\hline
\end{tabular}

Table 8. Geometric mean egg selenium concentration ( $\mu \mathrm{g} / \mathrm{g}$, dry weight) for bird eggs collected from 2003 through 2006 from the Panoche Drainage District's reuse area.

\begin{tabular}{|l|l|l|l|l|}
\hline \multicolumn{1}{|c|}{ species } & \multicolumn{1}{|c|}{$\mathbf{2 0 0 3}$} & \multicolumn{1}{|c|}{$\mathbf{2 0 0 4}$} & \multicolumn{1}{|c|}{$\mathbf{2 0 0 5}$} & \multicolumn{1}{c|}{$\mathbf{2 0 0 6}$} \\
\hline killdeer & 12.5 & 13.1 & 15.9 & 22.8 \\
\hline recurvirostrids (avocets and stilts) & 39.0 & 15.3 & 35.3 & 23.0 \\
\hline red-winged blackbirds & 5.9 & 6.0 & N/A & 8.8 \\
\hline
\end{tabular}

Data inputs: San Joaquin River Water Quality Improvement Project, Phase I Wildlife Monitoring Reports: Harvey and Associates, 2004 and 2006. Number in parentheses = number of eggs.

A compilation of data from 2003 through 2006 (tables 7 and 8) shows ranges and geometric mean selenium concentrations in bird eggs collected from the Panoche Drainage District reuse area. Selenium concentrations in bird eggs were consistently above concentrations associated with selenium toxicity to embryos during those four years. Selenium concentrations in avocets and stilts in 2006 exceeded $90 \mu \mathrm{g} / \mathrm{g}$ dry weight, higher than during the flooding event of 2003. A bird egg selenium concentration of $90 \mu \mathrm{g} / \mathrm{g}$ dry weight is 9 -fold higher than the substantive risk threshold in bird eggs and deformed embryos would be expected.

The Panoche Drainage District has recently instituted additional measures to reduce selenium exposure of birds including:

- decreasing the attractiveness of drainage ditches by netting or enclosing drains;

- hazing birds nesting near irrigation and drainage ditches;

- planning for the contingency of flooded fields; and

- providing 50-acres of mitigation habitat.

Provision of mitigation habitat acreage with a dedicated water source would compensate for decreased nesting on re-use habitat. Evaluation would be necessary to see whether the amount of mitigation was appropriate or successful, and what mitigation ratio should be applied to future reuse areas.

The enhanced solar evaporator systems would be used at conditions that yield evaporation rates $>90 \%$ so that residual liquid spray is minimized to the point that ponding does not occur. However, ponding has occurred in the past at the pilot project solar evaporator basin at Red Rock Ranch. In 1996, enough ponding occurred within the solar evaporator to attract birds to nest. Nests were also found at the adjacent reuse area where halophytes were being irrigated with concentrated drainwater. Use of 
concentrated drainage resulted in geometric mean selenium concentrations in stilt eggs of $58 \mu \mathrm{g} / \mathrm{g}$ dry weight, with $56.7 \%$ of the stilt embryos deformed. This is the highest incidence of selenium-induced avian teratogenesis reported by any field study to date. Killdeer, a species of bird known to feed over a wider range, showed a 14\% rate of deformity. The recently proposed enhanced solar evaporators are to receive water at a selenium concentration of $10 \mu \mathrm{g} / \mathrm{L}$. However, at this concentration there still may be a potential for selenium risk to wildlife, if performance does not meet specific criteria.

A buffer zone of approximately 600 feet was suggested to protect agricultural crops from redeposition of salt downwind from sprinklers. Selenium concentrations were not measured to determine or assess spray drift of salt or selenium that may affect wildlife or human health (California Department of Water Resources, 2005). Airborne particulates from salt waste piles may provide an additional pathway of exposure to plants, wildlife, and humans for selenium and other trace elements.

\section{Drainage Treatment}

Selenium removal from agricultural drainage from the western San Joaquin Valley is hampered by the large amounts of associated salt in any waste stream subjected to treatment. Extensive testing of technologies for removal of selenium from the water-column utilizing chemical and biological processes as part of the SJVDP achieved little operational success or cost-effectiveness (SJVDP, 1990c). Drainage treatment to remove selenium was not one of the strategies recommended by the SJDVP (1990a). In the Preface to the San Joaquin Valley Drainage Program final report (1990a), Edgar Imhoff, head of the program, wrote that "...hopes for a master drain and expectations of a technological breakthrough in drainage water treatment are the reasons that the drainage problem has grown to nearly 500,000 acres and is adversely affecting the environment."

A review of treatment technologies in 2004, evaluated the advantages and disadvantage of a number of technologies specifically tested on agricultural drainage waters from the valley. Some initial reduction of selenium concentration is possible (e.g., from $400 \mu \mathrm{g} / \mathrm{L}$ to $100 \mu \mathrm{g} / \mathrm{L}$ ), but achieving levels low enough to meet regulatory requirements $(2-5 \mu \mathrm{g} / \mathrm{L})$ to protect the environment were found difficult and expensive.

Technologies for treatment and disposal of waste products as planned in the SLDFRE EIS alternatives were tested on pilot-project scale. Pilot projects for drainage treatment using RO and biotreatment are located in: (1) the Westlands Water District in partnership with the California Department of Water Resources and Red Rock Ranch Incorporated; and (2) the Panoche Drainage District.

Different RO treatment technologies are being tested with various pretreatment steps to separate detrital material and salts such as calcium sulfate from the drainwater to prevent clogging and improve recovery of product water (e.g., tubular nano-filtration membranes, addition of amendments, vibrating membranes). Bio-treatment technologies utilize bacteria that metabolize selenium. Granular charcoal and the development of a biological film to support bacterial reduction transform dissolved selenium to a solid form. Enhanced evaporation technologies are being tested at Red Rock Ranch, the original site for using natural solar evaporation and spray technology.

Documentation for selenium bio-treatment in the SLDFRE EIS states that, "The pilot test has also encountered and identified numerous design and operational deficiencies that have impaired the performance of the bio-reactors during the first half of 2004. Selenium concentrations in the treated effluent during this period have been variable but generally range between 15 and $100 \mathrm{ppb}$." As stated in the initial SLDFRE DEIS: "Subsequent treatment and disposal of reused drainwater is dependent upon the TDS concentrations. Biological treatment of drainwater may not be effective or economical at 
TDS concentrations above 20,000 mg/L." Hence two disposal schemes were differentiated based on drainwater TDS concentration: $<20,000 \mathrm{mg} / \mathrm{L}$ TDS through a sequence that includes biological treatment; and $>20,000 \mathrm{mg} / \mathrm{L}$ TDS through a sequence that uses enhanced evaporation system and thermal desalinization (SLDFRE DEIS, Section 2).

In the recent drainage management proposal, the planned TDS concentration of the drainwater is $32,520 \mathrm{mg} / \mathrm{L}$ as it is discharged from the RO step and enters the selenium bio-treatment step. Data compilations (SLDFRE FEIS appendix B, attachment B-2) show that conductivity of the test waters for biological treatment ranges from 4,200 to approximately $15,000 \mu \mathrm{S} / \mathrm{cm}$. If conductivity measurements are converted to TDS measurements (conductivity X $0.76=$ TDS), the range of TDS in selenium biotreatment test water becomes 3,192 to $12,692 \mathrm{mg} / \mathrm{L}$. Salinity for the Panoche Drainage District test waters for the selenium bio-treatment system ranged from 5,400 to $16,700 \mu \mathrm{g} / \mathrm{L}$. Thus, these TDS concentrations are at least two-fold below that level predicted as output from an RO facility. The compilation also shows over a three-month period of operation using a test solution of approximately $10,050 \mathrm{mg} / \mathrm{L}$ TDS, that the selenium concentration in the effluent increased from $1.6 \mu \mathrm{g} / \mathrm{L}$ to $200 \mu \mathrm{g} / \mathrm{L}$ (i.e., an approximate 125-fold drop in efficiency). This testing is at an almost 3 -fold dilution of the TDS concentration planned for the $\mathrm{RO}$ effluent that is to be subjected to selenium bio-treatment. The matrix of chemicals in the drainwater used to test selenium bio-treament also is not described. Results were also variable in terms of discharging an effluent that is predominantly selenate as originally required in the SLDFRE EIS to meet environmental needs. As mentioned previously, selenite and organo-selenium would be more readily taken up in the environment than selenate (Skorupa, 1998; refer to previous discussion). In response to comments provided for the SLDFRE EIS, the USBR stated that a nationally recognized water treatment expert will conduct an independent review of the RO and selenium biotreatment pilot studies, data analyses, and design assumptions by 2006.

In their original conception, solar evaporation basins would be small and serve each farm on its own specific scale. The planned enhanced evaporation technologies were tested at a pilot project solar evaporator basin of 0.23 acres located at Red Rock Ranch (California Department of Water Resources, 2006), the original site for using natural solar evaporation and spray technology (named Integrated onFarm Drainage Management or IFDM). The proposed enhanced solar evaporators would cover an area of 330 acres in the Westland Area and the Northerly Area (six facilities of 110 acres each), a scale-up of approximately 1400-fold in both the Westlands Area and the Northerly Area.

\section{Final disposition: disposal of bio-waste, storage of salts, and closure plans}

Further tracking of the final disposition of salt and bio-waste to dedicated disposal areas would be necessary to complete the entire quantification and impact evaluation of the proposed waste-stream. The assumed combined flow rate to the bio-treatment facility in the recently proposed drainage management plan is approximately 6,850 AF/year. Bio-treatment modules are planned for treating 1000 AF/year with shared flushing systems. The SLDFRE EIS states that the bio-treatment sludge will be disposed of in accordance with applicable regulations. Additionally, flushing decant water from various process steps would be disposed of in evaporation ponds or recycled back to the treatment plant (SLDFRE EIS, Appendix B). The more recent plan states that solid bio-waste will be disposed/reused appropriately. 
The concentration of selenium in liquids associated with the sludge bio-waste in the scenarios illustrated in figures 6-12 may be as high as $1,068 \mu \mathrm{g} / \mathrm{L}$ if a two-fold concentrating factor is assumed. The final concentration of selenium in the bio-waste would depend on an assumed density, but the potential exists for the production of liquids and solids that would be designated or hazardous selenium wastes. The selenium criteria for a hazardous waste are $1,000 \mu \mathrm{g} / \mathrm{L}$ for a liquid and $100 \mu \mathrm{g} / \mathrm{g}$ wet weight for a solid (U.S. Department of Health and Human Services, 1996).

If 100,000 acres of land is retired under the Groundwater Quality alternative, then 412,772 tons salt/year are available for storage at the end of the evaporation process. Assuming a bulk dry density of $1 \mathrm{~g} / \mathrm{cm}^{3}$, then 13.24 million feet $^{3}$ salt are produced per year. At one-foot depth, this amount would cover 311 acres. In 50 years, the salt waste pile would rise to $50 \mathrm{ft}$ on the assumed 311 acres. This amount would be produced each 50 years into perpetuity.

As noted before, airborne particulates from salt waste piles may provide an additional pathway of exposure to wildlife and humans. Air quality problems may arise from wind-driven salt particles containing selenium. Hence, given the scale of the project, there is a need to understand the wind patterns of the valley and the composition and physical properties of exposed salt or other solid waste products

If 100,000 acres of land is retired under the Groundwater Quality alternative, then 13,406 lbs selenium/year in bio-waste needs disposal at the end of the waste-stream. At the end of a 50-year span of the project, 670,300 lbs selenium would need disposal to landfill. This amount would be available each 50 years into perpetuity. This magnitude of storage on land surface has long-term implications for the future of the western San Joaquin Valley as land-use changes take place.

Calculation of the useful life of treatment facilities also would be a necessary to complete the depiction of overall treatment impacts to the landscape. Closure plans for evaporation ponds built for disposal of agricultural drainage in the Tulare and Kern subareas of the western San Joaquin Valley have been implemented in the past. However, the scale of decommissioning of proposed treatment and disposal areas would be of a much greater magnitude. 


\section{Concluding Perspective}

The success of SLDFRE EIS alternatives and recently proposed drainage management plans relies heavily on above ground storage of salt and selenium and the development of successful technologies for selenium treatment and evaporation of water to concentrate salt. A scenario that successfully scales-up drainage water reuse, selenium bio-treatment, and evaporation of water to concentrate salt to magnitudes effective in treating planned volumes of drainflow may create new selenium exposure pathways that pose potential risks at levels that are currently undefined. However, selenium risk may be greatest at reuse areas. A 4,000-acre pilot project reuse area has consistently had significantly elevated selenium in bird eggs for the last five years.

If selenium treatment is not ultimately successful the recent plan appears to rely upon increasing the amount of land retired. Land retirement, however, may be passive, may resolve only on-site drainage issues, and may not maximize the sustainability of agriculture, unless land is specifically retired to address a certain need and actively managed for a specific purpose (e.g., creation of habitat). The lack of a successful treatment technology for drainage also may ultimately mean an expansion of bare-soil evaporation within the valley. In contrast, a hydrogeologic approach with a regional groundwater management strategy has the potential to extend the viability of agriculture and minimize ecological risks of surface treatment and disposal. Further understanding of how ground-water flow is linked to selenium and salt transport would be necessary to quantify potential degradation of aquifer resources that might accompany such a regional program.

Optimizing various drainage management paths to meet agricultural, environmental, and wateruse needs in the future may be better addressed by a more formal decision-making process. An approach such as Decision Analysis (refer to appendix B for a description of the components of Decision Analysis) could explicitly derive a mix of strategies with associated benchmarks, performance guidelines (e.g., triggers) and contingency options that would be needed to achieve a certain quantitative outcome. In essence, this type of approach would link models of such drainage reduction activities as conservation and reuse of agricultural water; land retirement; and groundwater extraction on a regional scale. A second tier of modeling would address selenium exposure (i.e., ecosystem scale models of how selenium is processed through valley food webs to vulnerable species of concern) to establish a firstorder understanding of relevant conditions, biological responses, and ecological risk should this revised proposal be implemented. Additional tiers of modeling would address other societal issues or issues of concern. Such balancing and selection of the mix of strategies of drainage reduction would support and document decision-making under the conditions of uncertainty and risk inherent in the proposed project.

Specific drainage management pathways and associated goals for the proposed drainage management plan are:

1. Measure acre-feet per acre to work towards achieving a specified drainage production rate (e.g., 0.25 to $0.16 \mathrm{AF} /$ acre/year).

2. Track selenium and salt through implemented drainage reduction options (improved irrigation efficiency; shallow groundwater management; regional recycling; seepage reduction; and regional groundwater pumping) on a mass balance basis (i.e., measure volume or flow, concentration, and load) to work towards achieving load targets (lbs selenium or tons salt/acre or $\mathrm{AF} /$ year) based on AF/acre/year performance from above. 
3. Develop a land retirement selection plan with incentives to work towards achieving maximum containment of selenium in the aquifer by intentionally retiring large areas of land underlain by a shallow groundwater containing selenium concentration of $>50 \mu \mathrm{g} / \mathrm{L}$.

4. Decrease the attractiveness (e.g., netting of drainage ditches, hazing of birds) of reuse area as habitat for birds and wildlife to work towards achieving minimum selenium exposure in the environment.

5. Develop bird and wildlife use models and monitor nesting to work towards achieving provision of mitigation habitat at a ratio appropriate in size to expected use.

6. Develop contingency plans for accidental and natural flood events for each component of drainage reduction and disposal to work towards achieving protection against acute toxic episodes of selenium exposure.

7. Track the composition (e.g., selenium and total dissolved solids) of waste-streams and quantify volumes, concentrations, and loads for disposal to work towards achieving optimal effectiveness and sufficient capacity of treatment technologies to meet drainage disposal requirements of volume, concentration, and load from above.

8. Track acreage of solar evaporators, amounts of land-surface storage, and the hazardousness of solid material to work towards planning and achieving any additional societal land-use requests or requirements in the future. 


\section{References}

Barlow, P.M., Wagner, B.J., Belitz, K., 1996, Pumping strategies for management of a shallow water table: the value of the simulation-optimization approach: Ground Water, volume 34, No. 2, 305-317 p. Belitz, K., Phillips, S.P., and Gronberg, J.M., 1993, Numerical simulation of ground-water flow in the central part of the western San Joaquin Valley, U.S. Geological Survey Water-Supply Paper 2396, 69 p.

Belitz, K., and Phillips, S. P., 1995, Alternative to Agricultural Drains in California's San Joaquin Valley: Results of a Regional-Scale Hydrogeologic Approach: Water Resources Research, Vol. 31, 1845 to $1862 \mathrm{p}$.

Brush, C.F., Belitz, K., and Phillips, S.P., 2004, Estimation of a water budget for 1972-2000 for the Grasslands Area, central part of the western San Joaquin Valley, U.S. Geological Survey Scientific Investigations Report 2004-5180, version 1.1., 51 p.

Brush, C.F., Belitz, K., Phillips, S.P., Burow, K.R., and Knifong, 2006, MODGRASS: update of a ground-water flow model for the central part of the western San Joaquin Valley, U.S. Geological Survey Scientific Investigations Report 2005-5290, 81 p.

California Department of Water Resources, 2005, Atmospheric salt emissions from the concentration of agricultural drainage water by sprinkler evaporator: California Department of Water Resources Agreement No. 4600000435-01, California State University, Fresno (C. Krauter), 23 p.

California Department of Water Resources, 2006, Solar evaporator for integrated on-farm drainage management system at Red Rock Ranch, San Joaquin Valley, California: California Department of Water Resources, Fresno, California, 5 p. (http://www.sjd.water.ca.gov/publications/drainage/ifdmsolar/solarevap.pdf)

CH2M HILL, 1988, San Joaquin Valley hydrologic and salt load budgets prepared for the San Joaquin Valley Drainage Program under U.S. Bureau of Reclamation Contract No. 7-CS-20-05210, order No. 8-PD-20-05210/003, modification 003: CH2M HILL, Sacramento, California, 40 p.

Frankenberger, W.T., Jr., and others, 2004, Advanced treatment technologies in the remediation of seleniferous drainage waters and sediment, Irrigation and Drainage Systems, volume 18, p. 19-41. Kluwer Academic Publishers, Netherlands.

Gilliom, R.J., and others, 1989, Preliminary assessment of sources, distribution, and mobility of selenium in the San Joaquin Valley, California, U.S. Geological Survey Water-Resources Investigations Report, 88-4186, 129 p.

HT Harvey and Associates, September 2004, San Joaquin River Water Quality Improvement Project, Phase I, Wildlife Monitoring Report 2003. Prepared by HT Harvey and Associates, Fresno, CA for Panoche Drainage District, Firebaugh, CA, 42 pp.

HT Harvey and Associates, May 2005, San Joaquin River Water Quality Improvement Project, Phase I, Wildlife Monitoring Report 2004. Prepared by HT Harvey and Associates, Fresno, CA for Panoche Drainage District, Firebaugh, CA, 37 pp.

HT Harvey and Associates. June 2006. San Joaquin River Water Quality Improvement Project, Phase I, Wildlife Monitoring Report 2005. Prepared by HT Harvey and Associates, Fresno, CA for Panoche Drainage District, Firebaugh, CA, $47 \mathrm{pp}$ and attachment

HT Harvey and Associates. November 2007. San Joaquin River Water Quality Improvement Project, Phase I, Wildlife Monitoring Report 2006. Prepared by HT Harvey and Associates, Fresno, CA for Panoche Drainage District, Firebaugh, CA, 60 pp.

Presser, T.S., and Ohlendorf, H.M., 1987, Biogeochemical cycling of selenium in the San Joaquin Valley, California, USA: Environmental Management, v. 11, p. 805-821.

Presser, T.S., 1994, The Kesterson effect: Environmental Management, v. 18, p. 437-454. 
Presser, T.S., and Piper, D.Z., 1998, Mass balance approach to selenium cycling through the San Joaquin Valley, sources to river to bay, in Frankenberger, W.T., Jr., and Engberg, R.A., eds., Environmental Chemistry of Selenium: New York, New York, Marcel Dekker Inc., p. 153-182. Presser, T.S. and Luoma, S.N. 2006, Forecasting selenium discharges to the San Francisco

Bay-Delta Estuary: ecological effects of a proposed San Luis Drain extension, U.S. Geological Survey Open-File Report 00-416, 196 p.

Purkey, D.R., and Wallender, W.W., 2001, Drainage reduction under land retirement over a shallow water table: Journal of Irrigation and Drainage Engineering, volume 127, no.1, pp.1-7.

San Joaquin Valley Drainage Program, 1990a, A management plan for agricultural subsurface drainage and related problems on the westside San Joaquin Valley: San Joaquin Valley Drainage Program, Sacramento, California, $183 \mathrm{p}$.

San Joaquin Valley Drainage Program, 1990b, Fish and wildlife resources and agricultural drainage in the San Joaquin Valley, California, volumes I and II: San Joaquin Valley Drainage Program, Sacramento, California, 878 p. and 2 appendices.

San Joaquin Valley Drainage Program, 1990c, Agricultural drainage treatment technology review:

Memorandum Report, San Joaquin Valley Drainage Program, Sacramento, California, 183 p.

San Joaquin Valley Drainage Implementation Program, 1998, Drainage management in the San Joaquin Valley - A status report: San Joaquin Valley Drainage Implementation Program, California, Department of Water Resources, Sacramento, California, $65 \mathrm{p}$.

San Joaquin Valley Drainage Implementation Program, 1999, Land retirement technical committee final report: The San Joaquin Valley Drainage Implementation Program and the University of California Salinity/Drainage Program, $120 \mathrm{p}$.

Schoups, G., Hopmans, J.W., Young, C.A., Vrugt, J.A., Wallender, W. W., Tanji, K.K., Panday, S., 2005, Sustainability of irrigated agriculture in the San Joaquin Valley, California: Proceedings of the National Academy of Sciences. Volume 102. No. 43, p. 15352-15356.

Skorupa, J.P., 1998, Selenium poisoning of fish and wildlife in nature: lessons from twelve real-world examples, in Frankenberger, W.T., Jr., and Engberg, R.A., eds., Environmental Chemistry of Selenium: New York, New York, Marcel Dekker Inc., p. 315-354.

U.S. Bureau of Reclamation, 2001, Preliminary alternatives report, San Luis Unit Drainage feature reevaluation: U.S. Bureau of Reclamation Mid-Pacific Region, Sacramento, California, 132 p.

U.S. Bureau of Reclamation, 2002, Plan formulation report, San Luis Unit drainage feature reevaluation: U.S. Bureau of Reclamation Mid-Pacific Region, Sacramento, California, 160 p.

U.S. Bureau of Reclamation, 2004, Plan formulation report addendum, San Luis Unit drainage feature re-evaluation: U.S. Bureau of Reclamation Mid-Pacific Region, Sacramento, California, 6 chapter and appendices.

U.S. Bureau of Reclamation, 2005, Draft Environmental impact statement on the San Luis drainage feature re-evaluation: U.S. Bureau of Reclamation, Mid- Pacific Region, Sacramento, California, $1,591 \mathrm{p}$.

U.S. Bureau of Reclamation, 2006, Final Environmental impact statement on the San Luis drainage feature re-evaluation: U.S. Bureau of Reclamation, Mid- Pacific Region, Sacramento, California, $2785 \mathrm{p}$.

U.S. Bureau of Reclamation, 2007, Record of Decision for the Final Environmental impact statement on the San Luis drainage feature re-evaluation: U.S. Bureau of Reclamation, Mid- Pacific Region, Sacramento, California, $37 \mathrm{p}$.

U.S. Bureau of Reclamation, 2008, San Luis Drainage Implementation Plan (Handout \#4) dated $3 / 12 / 08$. 
U.S. Department of the Interior, 1998, Constituents of concern: selenium, in Guidelines for interpretation of the biological effects of selected constituents in biota, water, and sediment, National Irrigation Water Quality Program Information Report No. 3: National Irrigation Water Quality Program, U.S. Department of the Interior, Washington, DC, p. 139-184.

U.S. Fish and Wildlife Service Conceptual Monitoring, Compliance, and Adaptive Management Plan for the San Luis Unit Drainage Management Plan, December, 2007 draft; and February, 2008 draft: U.S. Fish and Wildlife Service, Sacramento, California, 75 pages and appendices 


\section{Appendix A: Description of Drainage Management Alternatives and Plans}

Land retirement alternatives have been refined throughout the development of SLDFRE EIS to accommodate requests for additional detailed alternatives that build on previous analyses of strategies. The definition of land retirement for some lands retired under different settlement agreements may include continuing the production of these lands through use of groundwater and water from sources other than from the Central Valley Project for irrigation. Land retirement alternatives analyzed and illustrated from the SLDFRE EIS (Section 2) are:

In-valley (initial generalized alternative): Minimum land retirement assumption is 44,106 acres for the Westland Area for all action alternatives (common element) compared to existing conditions and No Action. Retired lands are assumed to be managed as dryland farming, grazed, or fallowed. Existing conditions in 2002 showed 20,518 acres subject to land retirement. The No-Action Alternative showed 109,106 acres out-of-production. These acres include 65,000 acres as part of the WWD settlement; 34,100 acres as part of the Sumner Peck Ranch et al settlement; 3,000 acres as part of the Britz Settlement; and 7,000 acres as part of the Reclamation CVPIA Land Retirement Program.

Groundwater Quality Land Retirement Alternative:... "consists of retiring all the lands in Westlands with Se concentration greater than $50 \mathrm{ppb}$ in the shallow groundwater and lands acquired by Westlands (that could be brought into production with drainage service, Table 2.3-1). It would also retire 10,000 acres in Broadview Water District in the Northerly Area. Total land retirement is about 92,600 acres (44,106 plus additional 48,486 acres). This alternative includes irrigation system improvements to reduce deep percolation to shallow groundwater."

Water Needs Land Retirement Alternative:..."would retire lands such that the water needs of the lands remaining in production could be met by the Unit's foreseeable water supply from its CVP contracts and groundwater resources. This results in an estimated 194,000 acres retired (44,106 plus 149,850 additional acres). This estimate of land retirement is a planning level approximation and should not be viewed as a firm prediction of future water supply or water needs. For purposes of SLDFR analyses for plan formulation and this EIS, the Unit's available water supply is based on the five districts receiving an average of 70 percent of their existing CVP contract amounts totaling 1,399,100 $\mathrm{AF} / \mathrm{yr}$ (or about 979,400 AF/yr) plus local groundwater supplies (about 185,000 AF/yr) for a total available water supply of 1,164,400 AF/yr. This acreage value would include lands with Se concentrations greater than $20 \mathrm{ppb}$ in Westlands, lands acquired by Westlands (that could be brought into production with drainage service, Table 2.3-1) and 10,000 acres in Broadview Water District. The alternative would include irrigation system improvements to reduce deep percolation to shallow groundwater. The irrigation system improvement program would be similar to that described in Section 2.4 for the In-Valley Disposal Alternative. 
Drainage-Impaired Area Land Retirement Alternative:..."would retire 308,000 acres (44,106 plus 263,894 acres), including all of the drainage-impaired lands in Westlands -approximately 298,000 acres. The Northerly Area (non-Westlands) is excluded from land retirement except for 10,000 acres in Broadview Water District. Drainage collection, treatment, and disposal facilities would not be needed in the Westlands drainage-impaired areas. The alternative would include irrigation system improvements to reduce deep percolation to shallow groundwater. The irrigation system improvement program would be similar to that described in Section 2.4 for the In-Valley Disposal Alternative, but would occur only in the Northerly Area. Lands remaining in production within the Northerly drainage-impaired area would be eligible for drainage service as under the previous alternative. The collection, treatment, and disposal of drainwater collected from drained lands would be only those needed to serve the Northerly Area

\section{SLU Plan proposed in USFWS Conceptual Monitoring, Compliance, and Adaptive Management Plan: 2/28/08 draft}

Table 1.Discrepancies between SLDFR in-valley alternatives and Westlands Drainage Plan.

\begin{tabular}{|c|c|c|c|}
\hline Plan Features & $\begin{array}{l}\text { SLDFR FEIS In-Valley/ } \\
\text { Groundwater Quality } \\
\text { Alternative }\end{array}$ & $\begin{array}{l}\text { SLDFR FEIS In-Valley/ } \\
\text { Water Needs Alternative }\end{array}$ & $\begin{array}{l}\text { WWD } \\
\text { Drainage Plan }\end{array}$ \\
\hline $\begin{array}{l}\text { Acres with Tile Drains Installed } \\
\text { (Northerly Area and WWD) }\end{array}$ & 187,116 & 122,833 & $122,833^{1}$ \\
\hline Acres of Land Retirement & 92,592 (in WWD) & $\begin{array}{l}193,956 \text { (in WWD and } \\
\text { Broadview WD) }\end{array}$ & $100,000^{1}$ \\
\hline $\begin{array}{l}\text { Drainage Volume before reduction } \\
\text { (AF/Year) }\end{array}$ & 85,000 & 63,000 & $63,000^{2}$ \\
\hline \# Of Reuse Areas (WWD) & 14 & 13 & $15^{1}, 12^{2}$ \\
\hline $\begin{array}{l}\text { Acres of Reuse Areas (Northerly Area and } \\
\text { WWD) }\end{array}$ & 16,700 & 12,500 & $12,500^{2}$ \\
\hline $\begin{array}{l}\text { Drainage Inflow to Reverse Osmosis } \\
\text { Treatment (Northerly Area and WWD) }\end{array}$ & $18,458 \mathrm{AFY}$ & $13,730 \mathrm{AFY}$ & $13,730 \mathrm{AFY}^{1}$ \\
\hline Flowrate to Biotreatment (WWD) & 5,179 AFY & $2,815 \mathrm{AFY}$ & $2,815 \mathrm{AFY}^{1,2}$ \\
\hline
\end{tabular}




\section{SLU Plan proposed in USBR Handout \#4, San Luis Unit Drainage Implementation Plan, dated} 2/12/08.

Table I-1 below identifies the proposed system drainwater reduction and treatment capability consistent with projected future on-farm operations at full capacity

\begin{tabular}{|c|c|c|}
\hline \\
\hline Component & Characteristic & Value \\
\hline Drainage Area & Acres w/ tile drains & 122,833 \\
\hline On-Farm Drainwater Reduction & Volume reduced per year (AF) & 2,970 \\
\hline Regional Drainwater Reduction & Volume reduced per year (AF) & 4,200 \\
\hline Other Drainwater Reduction & Volume reduced per year (AF) & 10,350 \\
\hline Drainage Rate After above Reductions & Drainage Volume per year (AF) & 45,287 \\
\hline \multirow[t]{2}{*}{ Drainage Reuse } & & \\
\hline & Vol. reduction Westlands per yr (AF) & 12,827 \\
\hline \multirow[t]{2}{*}{ Drainage Rate After Reuse } & Volume in AF/yr (average) & 13,730 \\
\hline & Flow rate in cfs (average) & 19.0 \\
\hline \multirow[t]{7}{*}{$\begin{array}{l}\text { Drainage Treatment } \\
\text { (Current Est.) }\end{array}$} & $\begin{array}{l}\text { Initial average Se concentration of reused } \\
\text { drainwater }(\mu \mathrm{g} / \mathrm{L})\end{array}$ & 120 \\
\hline & $\begin{array}{l}\text { Final average Se concentration of reused } \\
\text { drainwater }(\mu \mathrm{g} / \mathrm{L})\end{array}$ & 270 \\
\hline & Volume to RO treatment per year (AF) & 13,730 \\
\hline & Volume to Se biological treatment per year (AF) & 6,865 \\
\hline & $\begin{array}{l}\text { Average Se concentration in influent to solar evap } \\
\text { units }(\mu \mathrm{g} / \mathrm{L})\end{array}$ & 10 \\
\hline & $\begin{array}{l}\text { Initial average TDS concentration at point of } \\
\text { discharge }(\mathrm{mg} / \mathrm{L})\end{array}$ & 13,700 \\
\hline & $\begin{array}{l}\text { Final average TDS concentration at point of } \\
\text { discharge }(\mathrm{mg} / \mathrm{L})\end{array}$ & 27,600 \\
\hline \multirow[t]{2}{*}{ Land Conveyance } & Miles of pipe & $<71$ \\
\hline & Miles of canal & 0 \\
\hline
\end{tabular}




\section{Appendix B: Decision Analysis Modeling}

As an Adaptive Management tool Decision Analysis would:

- formalize data-gathering, planning, and implementation decisions and analyze their consequences on appropriate scales (i.e., local, regional, and state);

- organize individuals and their expertise into a working group whose members are encouraged to investigate the relationships between their disciplinary boundaries in a way that makes the overall model and solution pathways more relevant and durable.

Thus, Decision Analysis would involve all agencies and stakeholders in a quantitative and an analytically-focused overarching vision of the challenges and risks at hand. In turn, an integrative scientific basis of understanding is built to enable consensus-building and inform cooperative monitoring and compliance activities.

Decision Analysis is tailored to the specific decision being addressed, but it generally follows five steps:

Frame the Problem. Identify the decision context, the decision-makers(s), and stakeholders. The purpose of this step is to develop a clear statement of the decisions being addressed, and to identify the roles, goals, and interests of the decision-makers and stakeholders in the overall process.

Identify Objectives, Alternatives, and Uncertainties. A fundamental feature of the Decision Analysis approach is the decomposition of any decision problem into three basic components: what the decision maker wants (his or her objectives), what they can do (the decision alternatives), and other factors that the decision-maker does not control but that can affect the outcome of a decision (uncertainties). Developing a clear identification and statement of each of these components is critical to being able to conduct a useful analysis. Depending on the decision context, this step may include active participation of multiple stakeholders; stakeholders have an important role in identifying objectives, they may have a role in identifying alternatives, and they may also bring technical knowledge that is useful in identifying and quantifying uncertainties.

Build a Decision Model. Decision Analysis modeling is a process of quantifying the relationships between the decision alternatives and the ability for each alternative to meet the decisionmakers and/or stakeholders objectives. Only very rarely is there an unambiguous relationship between an alternative and the outcome of choosing that alterative - typically there are a variety of uncertainties that intervene, where the outcome of a particular alternative depends on things not fully understood at the time the decision must be made. Depending on the decision context, relevant uncertainties may include scientific uncertainties about the state of the physical and biological processes involved, "state of the world" uncertainties about, for example, future weather patterns or climate, policy-related uncertainties about, for example the future regulatory environment, and so forth. Building a decision model first requires specifying the relationships between the decision alternatives, uncertainties, and objectives, and then quantifying those relationships and the uncertainties. Quantification in a Decision Analysis model means both estimating the likelihood of various outcomes for a given uncertainty, and quantifying how well each alternative will perform against the specified objectives under each potential outcome of the uncertain factors. Decision Analysis includes a wide array of tools and processes to facilitate the model-building process. 
Conduct Analyses and Sensitivity Analyses. Once a model is built, there are many types of analyses that can be conducted to inform the decision-makers and stakeholders. The most appropriate and useful analyses depend on the decision context. For most real-world decision contexts there are multiple parties involved, multiple objectives are relevant, and there may be varying degrees of confidence in the quantification of the uncertain factors. In those cases, more sophisticated analyses and sensitivity analyses are necessary to fully elucidate the problem. Some examples of sensitivity analyses include:

$\checkmark$ Full quantification of the probability and net benefits of each alternative (in addition to calculation of the expected value): This is helpful in identifying situations where, perhaps, one alternative has a higher expected value, but with the potential for very good or very bad outcomes (a high variance alternative), and another alternative with a lower expected value has much less uncertainty about the outcome (a low variance alternative).

$\checkmark$ "Importance analyses" identifying the input uncertainties that have the most impact on the uncertainty in the outcomes: These analyses may point to areas of further research that would reduce the uncertainty about the outcome of a particular decision.

$\checkmark$ Decision policy uncertainty analyses, which are similar to importance analyses but focus on identifying which uncertainties are "decision relevant": Decision-relevant uncertainties are those where the optimal decision is different depending on the outcome of that uncertainty.

Decide and Execute. Ultimately, of course, the goal of Decision Analysis modeling is to support a decision or the selection of a preferred alternative. Like all models, however, Decision Analysis models are simply tools to be used by the decision-maker(s). No tool can "make a decision," but a high-quality Decision Analysis model can be used by the decision-makers to explore the implication of various choices in terms on the impact on objectives that they themselves specify based on their understanding of the science and what the future state of the world looks like. 